\title{
Impacts of snow and organic soils parameterization on northern Eurasian soil temperature profiles simulated by the ISBA land surface model
}

\author{
Bertrand Decharme $^{1}$, Eric Brun ${ }^{1, a}$, Aaron Boone ${ }^{1}$, Christine Delire ${ }^{1}$, Patrick Le Moigne ${ }^{1}$, and Samuel Morin ${ }^{2}$ \\ ${ }^{1}$ GAME-CNRM - UMR3589, CNRS/Météo-France, Toulouse, France \\ ${ }^{2}$ CEN ,GAME-CNRM - UMR3589, CNRS/Météo-France, Grenoble, France \\ a now at: ONERC, Ministry of Ecology, Paris, France \\ Correspondence to: Bertrand Decharme (bertrand.decharme@meteo.fr)
}

Received: 5 November 2015 - Published in The Cryosphere Discuss.: 10 December 2015

Revised: 25 March 2016 - Accepted: 29 March 2016 - Published: 18 April 2016

\begin{abstract}
In this study we analyzed how an improved representation of snowpack processes and soil properties in the multilayer snow and soil schemes of the Interaction SoilBiosphere-Atmosphere (ISBA) land surface model impacts the simulation of soil temperature profiles over northern Eurasian regions. For this purpose, we refine ISBA's snow layering algorithm and propose a parameterization of snow albedo and snow compaction/densification adapted from the detailed Crocus snowpack model. We also include a dependency on soil organic carbon content for ISBA's hydraulic and thermal soil properties. First, changes in the snowpack parameterization are evaluated against snow depth, snow water equivalent, surface albedo, and soil temperature at a $10 \mathrm{~cm}$ depth observed at the Col de Porte field site in the French Alps. Next, the new model version including all of the changes is used over northern Eurasia to evaluate the model's ability to simulate the snow depth, the soil temperature profile, and the permafrost characteristics. The results confirm that an adequate simulation of snow layering and snow compaction/densification significantly impacts the snowpack characteristics and the soil temperature profile during winter, while the impact of the more accurate snow albedo computation is dominant during the spring. In summer, the accounting for the effect of soil organic carbon on hydraulic and thermal soil properties improves the simulation of the soil temperature profile. Finally, the results confirm that this last process strongly influences the simulation of the permafrost active layer thickness and its spatial distribution.
\end{abstract}

\section{Introduction}

Snowpack properties are known to be of primary importance for understanding the water and energy budgets of the land surface, especially in mountainous and boreal regions. From autumn to spring, solid precipitation is stored within the snowpack, thereby modifying the terrestrial albedo and roughness length, and impacting the radiative and energy fluxes at the soil/atmosphere interface. During spring, the fresh water released by snowmelt contributes to soil infiltration, intense streamflow, and large seasonal flood events, and it directly modulates the land surface evapotranspiration (Poutou et al., 2004; Niu and Yang, 2006; Decharme and Douville, 2007). Snowpack also acts as an insulating layer at the surface which prevents significant heat loss in the winter. Over northern Eurasian regions, as discussed by Paquin and Sushama (2015), this last process controls the temperature of the permafrost. It is defined as a soil that remains below $0^{\circ} \mathrm{C}$ for 2 or more consecutive years, and it has a significant influence on the summer permafrost active layer thickness, defined as the maximum annual thaw depth. In summary, snowpack properties drastically influence soil/atmosphere interactions during a large part of the year through their impacts on many land surface processes.

Beside the importance of snowpack properties for understanding the water and energy budgets of the land surface in northern regions, the physical properties of soil organic carbon (or peat soil) also play a significant role. Northern Eurasian soils are very rich in organic carbon because the low soil temperatures in this region inhibit decomposition of 
dead plant material that accumulates over time, thereby forming peat deposits. Soil organic carbon exhibits very different hydraulic and thermal properties than mineral soil (Boelter, 1969; Letts et al., 2000). It is characterized by a very high porosity, a weak hydraulic suction, and a sharp vertical hydraulic conductivity profile from high values at the surface to very low values at the subsurface. This generally induces a relatively wet soil with a shallow water table (Letts et al., 2000). Its low thermal conductivity and its relatively high heat capacity act as an insulator for soil temperature that prevents the soil from significant warming during the summer (Bonan and Shugart, 1989; Lawrence and Slater, 2008). Over permafrost regions, the hydraulic and thermal properties of soil organic carbon partly control the soil depth reached by the $0^{\circ} \mathrm{C}$ isotherm which, in turn, defines the thickness of the active layer during summer (Paquin and Sushama, 2015). Through its influence on soil temperature and wetness, it impacts the continental part of the carbon cycle and the land surface $\mathrm{CO}_{2}$ and $\mathrm{CH}_{4}$ emissions to the atmosphere (Walter et al., 2006; Zimov et al., 2006).

In atmospheric, climate, and hydrological models, the dynamics of the snowpack and the evolution of water and heat profiles within the soil are simulated using so-called land surface models (LSMs). These LSMs, like the simple bucket scheme of Manabe (1969), were initially developed over 4 decades ago in order to simulate realistic land surface water and energy budgets in atmospheric general circulation models. Now, LSMs are used in many applications such as hydrological and meteorological forecasts, global hydrological and biogeochemical studies, and climate evolution prediction. Many LSMs use multilayer soil schemes in which the vertical transport of moisture and heat into the soil is explicitly solved for using diffusion equations (e.g., Decharme et al., 2011). Because the total soil depth is discretized using multiple layers, these schemes allow the representation of the vertical root distribution (Zeng et al., 1998; Feddes et al., 2001; Braud et al., 2005), as well as the surface/groundwater capillary exchanges (e.g., Vergnes et al., 2014). Finally, their coupling with a multilayer snowpack scheme permits a representation of the interaction between cold physical processes, such as the effect of snow on soil temperature, hydrology, and freezing (Slater et al., 2001; Luo et al., 2003; Gouttevin et al., 2012).

Three major classes of snowpack schemes exist in LSMs: single-layer schemes, multilayer schemes of intermediate complexity, and detailed snowpack models. The first class was used preferentially in the past within forecast and climate models. The snowpack was represented with only one layer that evolves seasonally, which is characterized as having a high albedo, a low thermal conductivity, and a low thermal capacity (Manabe, 1969; Verseghy, 1991; Douville et al., 1995). More recently, these simple single-layer schemes have been replaced by intermediate complexity models inspired by the pioneering work of Anderson (1976). These schemes use a multilayer approach with the minimum number of lay- ers needed to simulate all of the macroscopic physical properties of the snowpack such as albedo, compaction, density, and water refreezing (Lynch-Stieglitz, 1994; Loth and Graf, 1998; Boone and Etchevers, 2001; Brown et al., 2006; Oleson et al., 2010; Dutra et al., 2010; Shrestha et al., 2010; Best et al., 2011; Kuipers Munneke et al., 2011). Finally, more complex snowpack models have been developed primarily in support of avalanche forecasting, and more generally for all applications (including process studies) requiring a detailed representation of the vertical profile of the physical properties of snow. In addition to simulating macroscopic snowpack physical properties, they explicitly account for the time evolution of the snow microstructure driven by snow metamorphism, and the multiple feedback loops involving internal snow processes and the energy and mass balance at the air/snow and snow/ground interface (Brun et al., 1989, 1992; Jordan, 1991; Bartelt and Lehning, 2002). In addition, these models can serve as a reference for the development and evaluation of intermediate complexity snowpack schemes.

The Interaction Soil-Biosphere-Atmosphere (ISBA) LSM developed at Météo France currently uses a multilayer approach for the snowpack (Boone and Etchevers, 2001) and the soil (Boone et al., 2000; Decharme et al., 2011). ISBA is the land surface model embedded in the SURFEX (SURFace EXternalized) modeling platform (Masson et al., 2013), which is used in all of the atmospheric mesoscale, regionalscale, and global-scale models of Météo France, as well as in regional hydrological forecasting systems, global hydrological models, and model chains in support of avalanche hazard warning (e.g., Lafaysse et al., 2013; Vernay et al., 2016). The ISBA multilayer version was evaluated over many local or regional field data sets (Boone et al., 2000; Decharme et al., 2011, 2013; Canal et al., 2014; Parrens et al., 2014; Vergnes et al., 2014; Joetzjer et al., 2015), increasing our confidence in the model's capability to simulate realistic land surface processes under a variety of climate conditions. However, over cold regions, winter top soil temperatures tend to be underestimated (Wang et al., 2016), while during summer they are generally too warm. The first biases are attributable to the ISBA multilayer snowpack scheme of intermediate complexity developed by Boone et al. (2000) and based on Anderson (1976). Indeed, when the ISBA multilayer soil scheme is coupled with the detailed Crocus snowpack model, the winter soil temperature simulated at $20 \mathrm{~cm}$ depth better matches observations over the northern Eurasian regions (Brun et al., 2013). Secondly, ISBA only accounts for mineral soil properties, while many studies pointed out that the specific properties of soil organic carbon are required to realistically simulate the soil thermal regime over cold regions (Nicolsky et al., 2007; Beringer et al., 2001; Lawrence and Slater, 2008; Lawrence et al., 2008; Dankers et al., 2011).

The present study focuses on the impact of improving the representation of snowpack and soil properties in the ISBA LSM to reproduce snow characteristics and soil temperature profiles over cold regions. We replaced the original 
Boone and Etchevers (2001) representation of snow layering, albedo, and snow compaction by adapting some parameterizations used in the Crocus snowpack model (e.g., Vionnet et al., 2012). In addition, we added a parameterization of the organic carbon effect on hydraulic and thermal soil properties based on the pedotransfer function of Boelter (1969) and inspired by works of Letts et al. (2000) and Lawrence and Slater (2008). The changes in the snowpack parameterizations are first evaluated at the Col de Porte field site located in the French Alps (Morin et al., 2012). This data set includes many observations at a daily time step such as snow depth, snow water equivalent, surface albedo, and soil temperature at $10 \mathrm{~cm}$ from 1993 to 2011. In addition the meteorological observations required to drive the model are given at a 3hourly time step over the same period. The new parameterizations were evaluated next over the northern Eurasian region using the same experimental design as Brun et al. (2013) using in situ evaluation data sets of snow depth and soil temperature profile measurements and meteorological driving data from a global reanalysis. To quantify the model's ability to simulate the permafrost characteristics, two additional data sets were used that estimate the location of permafrost boundaries and the active layer thickness over the Yakutia region. A brief review of the ISBA multilayer model is given in Sect. 2; all of the snowpack and soil parameterization improvements and updates are presented in Sect. 3; Sects. 4 and 5 describe the model evaluation over the Col de Porte field site and the northern Eurasian region, respectively. Finally, a discussion and the main conclusions are given in Sect. 6.

\section{Review of the ISBA land surface model}

\subsection{Soil processes}

The ISBA multilayer model solves the one-dimensional Fourier law and the mixed-form of the Richards equation explicitly to calculate the time evolution of the soil energy and water budgets (Boone et al., 2000; Decharme et al., 2011). In each layer $i$, the closed-form equations between the soil liquid water content, $w\left(\mathrm{~m}^{3} \mathrm{~m}^{-3}\right)$, and the soil hydrodynamic parameters, such as the soil matric potential, $\psi(\mathrm{m})$, and the hydraulic conductivity, $k\left(\mathrm{~m} \mathrm{~s}^{-1}\right)$, are determined according to the Brooks and Corey (1966) model adapted by Campbell (1974) as follows:

$$
\begin{aligned}
& \psi(i)=\psi_{\text {sat }}(i)\left(\frac{w(i)}{w_{\text {sat }}(i)}\right)^{-b(i)} \text { and } \\
& k(i)=k_{\text {sat }}(i)\left(\frac{\psi(i)}{\psi_{\text {sat }}(i)}\right)^{-\frac{2 b(i)+3}{b(i)}},
\end{aligned}
$$

where $b$ represents the dimensionless shape parameter of the soil water retention curve, $w_{\text {sat }}\left(\mathrm{m}^{3} \mathrm{~m}^{-3}\right)$ the soil porosity, and $\psi_{\text {sat }}(\mathrm{m})$ and $k_{\text {sat }}\left(\mathrm{m} \mathrm{s}^{-1}\right)$ the soil matric potential and hydraulic conductivity at saturation, respectively. In this study, the heat and soil moisture transfers within the soil are computed using 14 layers up to a $12 \mathrm{~m}$ depth. The depth of the 14 layers $(0.01,0.04,0.1,0.2,0.4,0.6,0.8,1.0,1.5,2.0,3.0$, $5.0,8.0,12.0 \mathrm{~m}$ ) have been chosen to minimize numerical errors in solving the finite-differenced diffusive equations, especially in the uppermost meter of the soil (Decharme et al., 2011). Saturated hydraulic conductivity, matric potential at saturation, and porosity of the mineral soil are related to the soil texture (Noilhan and Lacarrère, 1995). The total heat capacity of the mineral soil in each layer is computed as the sum of the soil matrix, water, and ice heat capacities, weighted by the volumetric water and ice content (PetersLidard et al., 1998). The thermal conductivity of the mineral soil is computed via a more complex combination of water, ice, and soil conductivities as proposed by Peters-Lidard et al. (1998).

The soil ice content tendency (partial time derivative) is solved explicitly in each layer of the soil and accounts for ice sublimation and vegetation insulation effect at the surface (e.g., Boone et al., 2000). The liquid water content that can freeze is limited by a maximum value, $w_{\operatorname{lmax}}\left(\mathrm{m}^{3} \mathrm{~m}^{-3}\right)$, computed as a function of temperature based on the Gibbs free-energy method (Fuchs et al., 1978):

$$
w_{\operatorname{lmax}}(i)=w_{\mathrm{sat}}(i) \times \min \left[1.0,\left(\frac{L_{\mathrm{f}}}{g \psi_{\mathrm{sat}}(i)} \frac{T_{\mathrm{g}}(i)-T_{\mathrm{f}}}{T_{\mathrm{g}}(i)}\right)^{-1 / b(i)}\right],
$$

where $w_{\text {sat }}\left(\mathrm{m}^{3} \mathrm{~m}^{-3}\right)$ is the soil porosity in each layer $i, T_{\mathrm{g}}$ $(\mathrm{K})$ the soil temperature, $g\left(\mathrm{~m} \mathrm{~s}^{-2}\right)$ the terrestrial gravity constant, $T_{\mathrm{f}}(273.16 \mathrm{~K})$ is the triple-point temperature for water, and $L_{\mathrm{f}}\left(3.337 \times 10^{5} \mathrm{~J} \mathrm{~kg}^{-1}\right)$ the latent heat of fusion. The total water content in each soil layer is conserved during phase changes. When the soil freezes, the liquid water content will decrease, owing to a corresponding increase in soil ice content. Finally, the maximum temperature, $T_{\max }(\mathrm{K})$, used for phase changes can be determined via the same Gibbs freeenergy method:

$T_{\max }(i)=\frac{L_{\mathrm{f}} T_{\mathrm{f}}}{L_{\mathrm{f}}-g \psi(i)}$,

where the soil matric potential $\psi$ is defined using Eq. (1). Thus, this scheme induces dependencies of water phase changes on soil textures and on the degree of soil humidity. The coarser the soil texture, the larger the quantity of water that will freeze at a given temperature. As the soil becomes dry, the temperature that allows freezing drops. More details can be found in the supplementary material of Masson et al. (2013).

\subsection{Snowpack internal processes}

The original ISBA explicit multilayer snow scheme developed by Boone and Etchevers (2001) is a snowpack scheme 
of intermediate complexity made in order to take some processes into account such as snow mass and heat vertical redistribution, snow compaction, water percolation and refreezing, and explicit heat conduction at the snow/soil interface. Many of theses processes, such as snow compaction or absorption of solar energy, are based on works of Anderson (1976) and Loth et al. (1993). The thermal conductivity of snow (Appendix A) is computed via the snow density (Yen, 1981). An additional term depends on the snow temperature to account for vapor transfer through the snowpack (Sun et al., 1999). The time evolution of the snow mass is linked to snowmelt, water freezing, evaporation, and liquid flow. The liquid water content into the snowpack is simulated as a succession of bucket-type reservoirs. A maximum liquid-water-holding capacity $\left(W_{1 \max }\right)$ is computed in each layer. It varies from 3 to $10 \%$ of the snow mass according to a decrease in snow density after Anderson (1976). A liquid water flux is generated when the liquid water content exceeds this threshold. More details can be found in Boone and Etchevers (2001) and only internal physical processes of the snowpack discussed in this study are described below.

\subsubsection{Snow layering}

In the original ISBA explicit snow scheme, three layers are used for snow layering because it is considered to be the minimum number required to resolve adequately the snow thermal profile within the snowpack (Lynch-Stieglitz, 1994; Loth and Graf, 1998; Boone and Etchevers, 2001). The algorithm that computes the snow grid thicknesses $\Delta z$ of each layer, $i$, is described as follows:

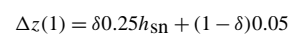

where $h_{\mathrm{sn}}(\mathrm{m})$ is the total snow depth. As long as the snow remains below $0.2 \mathrm{~m}$, the fraction of the total depth that defines the thickness of each layer remains with a fine resolution at the top and the base of the snowpack. When the snow depth exceeds $0.2 \mathrm{~m}$, the thickness of the first layer remains equal to $0.05 \mathrm{~m}$, in order to adequately solve the diurnal cycle of the surface energy balance. In addition, for large snow depth values, the second layer thickness cannot exceed $0.5 \mathrm{~m}$ because density and heat vertical gradients are generally the largest near the top of the snowpack. The vertical grid is updated at the beginning of each time step before the computation of the other snowpack internal processes.

\subsubsection{Snow compaction}

The evolution of snow density, $\rho_{\mathrm{sn}}\left(\mathrm{kg} \mathrm{m}^{-3}\right)$ in each layer, $i$, is the sum of snow compaction due to the change in snow viscosity, $\eta$ (Pas), and settling due to freshly fallen snow, $\xi$ $\left(\mathrm{s}^{-1}\right)$, following Anderson (1976) and Loth et al. (1993):

$$
\begin{aligned}
\frac{1}{\rho_{\mathrm{sn}}(i)} \frac{\partial \rho_{\mathrm{sn}}(i)}{\partial t} & =\frac{\sigma(i)}{\eta(i)}+\xi(i) \text { with } \sigma(i) \\
& =g \sum_{j=1}^{i}\left[\Delta z(j) \rho_{\mathrm{sn}}(j)\right],
\end{aligned}
$$

where $\sigma(\mathrm{Pa})$ is the snow vertical stress. The snow viscosity and settling of new snow are solved using two empirical exponential functions of snow density and temperature, $T_{\mathrm{sn}}$ $(\mathrm{K})$ :

$$
\begin{aligned}
& \eta(i)=v_{0} \exp \left(v_{1}\left(T_{\mathrm{f}}-T_{\mathrm{sn}}(i)\right)+v_{2} \rho_{\mathrm{sn}}(i)\right) \\
& \xi(i)=s_{0} \exp \left(-s_{1}\left(T_{\mathrm{f}}-T_{\mathrm{sn}}(i)\right)-s_{2} \times \max \left(0, \rho_{\mathrm{sn}}(i)-\rho_{\mathrm{d}}\right)\right),
\end{aligned}
$$

where $\quad v_{0}=3.7 \times 10^{7} \mathrm{Pas}, \quad v_{1}=0.081 \mathrm{~K}^{-1}$, $v_{2}=0.018 \mathrm{~m}^{3} \mathrm{~kg}^{-1}, \quad s_{0}=2.8 \times 10^{-6} \mathrm{~s}^{-1}, \quad s_{1}=0.04 \mathrm{~K}^{-1}$, $s_{2}=0.046 \mathrm{~m}^{3} \mathrm{~kg}^{-1}$, and $\rho_{\mathrm{d}}=150 \mathrm{~kg} \mathrm{~m}^{-3}$ are empirical parameters calibrated by Anderson (1976). The minimum density of snow is constrained to be $50 \mathrm{~kg} \mathrm{~m}^{-3}$. The snowfall density, $\rho_{\text {snew }}\left(\mathrm{kg} \mathrm{m}^{-3}\right)$, is expressed as a function of wind speed, $V_{\mathrm{a}}\left(\mathrm{m} \mathrm{s}^{-1}\right)$, and air temperature, $T_{\mathrm{a}}(\mathrm{K})$, following an experimental study of Pahaut (1976):

$\rho_{\text {snew }}=a_{\rho}+b_{\rho}\left(T_{\mathrm{a}}-T_{\mathrm{f}}\right)+c_{\rho} V_{\mathrm{a}}^{1 / 2}$,

where the coefficients $a_{\rho}=109 \mathrm{~kg} \mathrm{~m}^{-3}, b_{\rho}=6 \mathrm{~kg} \mathrm{~m}^{-3} \mathrm{~K}^{-1}$, and $c_{\rho}=26 \mathrm{~kg} \mathrm{~s}^{1 / 2} \mathrm{~m}^{-7 / 2}$.

\subsubsection{Transmission of solar radiation and snow albedo}

The absorption of incident shortwave solar radiation, $R_{\mathrm{SW}}$ $\left(\mathrm{W} \mathrm{m}^{-2}\right)$, within the snowpack is solved over a single spectral band. It uses an exponential decrease of incoming radiation with snow depth (Anderson, 1976; Loth et al., 1993). Therefore, the net shortwave radiation $Q_{\mathrm{sn}}\left(\mathrm{W} \mathrm{m}^{-2}\right)$ absorbed by the snow level, $i$, is given by

$$
Q_{\mathrm{sn}}(i)=\left(1-\alpha_{\mathrm{sn}}\right) R_{\mathrm{sw}} \exp \left(-\sum_{j=1}^{i}\left[\beta_{\mathrm{sn}}(j) \Delta z(j)\right]\right),
$$

where $\alpha_{\mathrm{sn}}$ is the dimensionless snow albedo, and $\beta_{\mathrm{sn}}\left(\mathrm{m}^{-1}\right)$ the extinction coefficient of snow which is given by

$\beta_{\mathrm{sn}}(i)=C_{v} \rho_{\mathrm{sn}}(i) / \sqrt{d_{\mathrm{opt}}(i)}$.

As shown by Bohren and Barkstrom (1974), this extinction of snow is directly related to its density, the optical diameter $d_{\text {opt }}(\mathrm{m})$, and a constant $C_{v}=3.8 \times 10^{-3} \mathrm{~m}^{5 / 2} \mathrm{~kg}^{-1}$. The optical diameter is empirically linked to the snow density following a simple polynomial regression established by Anderson (1976):

$d_{\mathrm{opt}}(i)=\min \left(d_{\mathrm{max}}, g_{1}+g_{2} \times \rho_{\mathrm{sn}}(i)^{4}\right)$,

where $d_{\max }(\mathrm{m})$ is the maximum value equal to $2.796 \times 10^{-3} \mathrm{~m}$, and the coefficients $g_{1}=1.6 \times 10^{-4} \mathrm{~m}$, 
and $g_{2}=1.1 \times 10^{-13} \mathrm{~m}^{13} \mathrm{~kg}^{-4}$ were calibrated by Anderson (1976). The time evolution of snow albedo is modeled in a simple way using time constants after Douville et al. (1995). A linear decrease rate is used for dry snow and an exponential decrease is used for wet snow, while the snow albedo increases linearly with snowfall intensity (Boone and Etchevers, 2001). The snow albedo is constrained to be between its minimum value, $\alpha_{\min }=0.5$, and its maximum, $\alpha_{\max }=0.85$.

\section{Changes in explicit snow and soil schemes}

\subsection{Changes in snowpack internal processes}

\subsubsection{Snow layering}

Detailed snowpack models use more than a dozen layers to simulate the snow thermal profile and the snowpack stratigraphy well (Armstrong and Brun, 2008; Vionnet et al., 2012). This configuration allows a good computation of the diurnal cycle through the use of fine top layers, while bottom layers are also sufficiently thin to ensure a good computation of the heat conduction at the snow/soil interface. However, these models were rarely used in global atmospheric, climate, and/or hydrological models due to their high computational costs, partly due to the use of a large number of layers. For this reason, the multilayer snow scheme in ISBA was developed using only three layers, representing a good compromise between a reasonable simulation of the snow thermal profile (Boone and Etchevers, 2001) and a low computing time. Today, such computational limitations are less of a constraint and a larger number of layers can be used in this scheme. The number of snow layers in ISBA was increased to 12 with two fine layers at the top and the bottom of the snowpack using the following simple algorithm:

$$
\mid \begin{aligned}
& \Delta z(i)=\min \left(\delta_{i}, \frac{h_{\mathrm{sn}}}{12}\right) \forall i \leq 5 \text { or } \forall i \geq 9 \\
& \Delta z(6)=0.3 d_{\mathrm{r}}-\min \left[0,0.3 d_{\mathrm{r}}-\Delta z(5)\right] \\
& \Delta z(7)=0.4 d_{\mathrm{r}}+\min \left[0,0.3 d_{\mathrm{r}}-\Delta z(5)\right]+\min \left[0,0.3 d_{\mathrm{r}}-\Delta z(9)\right], \\
& \Delta z(8)=0.3 d_{\mathrm{r}}-\min \left[0,0.3 d_{\mathrm{r}}-\Delta z(9)\right] \\
& d_{\mathrm{r}}=h_{\mathrm{Sn}}-\sum_{i=1}^{5} \Delta z(i)-\sum_{i=9}^{12} \Delta z(i)
\end{aligned}
$$

where the constants are defined as $\delta_{1}=0.01 \mathrm{~m}, \delta_{2}=0.05 \mathrm{~m}$, $\delta_{3}=0.15 \mathrm{~m}, \delta_{4}=0.5 \mathrm{~m}, \delta_{5}=1 \mathrm{~m}, \delta_{9}=1 \mathrm{~m}, \delta_{10}=0.5 \mathrm{~m}$, $\delta_{11}=0.1 \mathrm{~m}$, and $\delta_{12}=0.02 \mathrm{~m}$. For a snow depth below $0.1 \mathrm{~m}$, each layer has the same thickness of $0.00833 \mathrm{~m}$. When the snow depth is above $0.2 \mathrm{~m}$, the thicknesses of the first and the last layers reach their constant values of 0.01 and $0.02 \mathrm{~m}$ respectively to reasonably resolve the diurnal cycle and the snow/soil heat exchanges. However, to keep the information of an historical snowfall event for as long as possible, the grid thicknesses are updated only if the two first layers or the last layer become too small or too large. This condition can be summed up as follows:

$$
\begin{aligned}
\Delta z(i)< & \frac{1}{2} \min \left(\delta_{i}, \frac{h_{\mathrm{sn}}}{12}\right) \text { or } \Delta z(i)>\frac{3}{2} \min \left(\delta_{i}, \frac{h_{\mathrm{sn}}}{12}\right) \\
& \forall i=\{1,2,12\} .
\end{aligned}
$$

For example, for a total snow depth of $1 \mathrm{~m}$, if the thickness of the top layer becomes lower than $0.005 \mathrm{~m}$ or greater than $0.015 \mathrm{~m}$ at the beginning of a time step, the layer thicknesses of the entire snowpack are recalculated with Eq. (11) and the snow mass and heat are redistributed accordingly. A similar algorithm was also developed for the six and nine layer cases, but these results are not reported here. In terms of snowpack layering, the main difference with the Crocus scheme is the fact that the total number of layers is constant, while in Crocus only the maximum number of layers is specified (typically 20 or 50) and the model dynamically uses a number of layers which varies in time within this predefined constraint (Vionnet et al., 2012).

\subsubsection{Snow compaction}

In the new version of the snow scheme, the evolution of snow density in each layer is due to snow compaction resulting from changes in snow viscosity (Brun et al., 1989) and windinduced densification of near-surface snow layers (Brun et al., 1997). This wind-driven compaction process is assumed to occur when wind velocity exceeds a threshold value that depends on snow surface characteristics. This process is especially important for simulating the evolution of the snow density over polar regions. Brun et al. (1997) pointed out that this process is also critical for reproducing the snow thermal conductivity and the snow temperature profile over these regions. Therefore, the time tendency of snow density in each layer is computed as follows:

$\frac{\partial \rho_{\mathrm{sn}}(i)}{\partial t}=\rho_{\mathrm{sn}}(i) \frac{\sigma(i)}{\eta(i)}+\max \left(0, \frac{\rho_{\mathrm{w} \max }-\rho_{\mathrm{sn}}(i)}{\tau_{\mathrm{w}}(i)}\right)$,

where $\rho_{\mathrm{w} \max }\left(\mathrm{kg} \mathrm{m}^{-3}\right)$ is the maximum density equal to $350 \mathrm{~kg} \mathrm{~m}^{-3}$ below which the snow densification occurs during wind-driven compaction, $\tau_{\mathrm{w}}$ (s) the compaction rate of this process (Appendix $\mathrm{B}$ ), and $\sigma(\mathrm{Pa})$ the vertical stress in each layer. This stress is computed as the weight of the overlaying layers. At the top of the snowpack, half the mass of the uppermost layer is used. The vertical stress in each layer is then given by

$$
\begin{aligned}
& \sigma(1)=\frac{g \Delta z(1) \rho_{\mathrm{sn}}(1)}{2} \\
& \sigma(i)=g \sum_{j=1}^{i-1}\left[\Delta z(j) \rho_{\mathrm{sn}}(j)\right] \quad \forall i>1
\end{aligned} .
$$

The snow viscosity is a function of snow density, temperature, and liquid water content, $W_{1}\left(\mathrm{~kg} \mathrm{~m}^{-2}\right)$, and it is given as follows: 


$$
\mid \begin{aligned}
& \eta(i)=\frac{\eta_{0}}{f_{\mathrm{W}}(i)} \frac{\rho_{\mathrm{sn}}(i)}{\rho_{0}} \exp \left(a_{\eta} \times \min \left(\Delta T_{\eta}, T_{\mathrm{f}}-T_{\mathrm{sn}}(i)\right)+b_{\eta} \rho_{\mathrm{sn}}(i)\right) \\
& f_{\mathrm{W}}(i)=1+10 \times \min \left(1.0, \frac{W_{\mathrm{l}}(i)}{W_{\mathrm{l} \max }(i)}\right)
\end{aligned},
$$

where $\eta_{0}$ (Pas) is a reference viscosity equal to $7622370 \mathrm{Pas}, \rho_{0}\left(\mathrm{~kg} \mathrm{~m}^{-3}\right)$ is a reference density equal to $250 \mathrm{~kg} \mathrm{~m}^{-3}, W_{1 \max }\left(\mathrm{kg} \mathrm{m}^{-2}\right)$ represents the maximum liquid-water-holding capacity (e.g., Sect. 2.2) and the constants $a_{\eta}=0.1 \mathrm{~K}^{-1}, b_{\eta}=0.023 \mathrm{~m}^{3} \mathrm{~kg}^{-1}$, and $\Delta T_{\eta}=5 \mathrm{~K}$. The viscosity dependence on snow temperature is limited according to Schleef et al. (2014) who pointed out that the impact of snow temperature on snow densification becomes negligible at low temperatures. The last dimensionless function, $f_{\mathrm{W}}$, describes the decrease of viscosity in the presence of liquid water. Finally, the snowfall density is computed as previously shown (Eq. 7).

\subsubsection{Transmission of solar radiation and snow albedo}

The absorption of incident shortwave solar radiation, $R_{\mathrm{SW}}$ $\left(\mathrm{W} \mathrm{m}^{-2}\right)$, within the pack is now solved over three spectral bands according to Brun et al. (1992). The first band ([0.3$0.8] \mu \mathrm{m}$ ) represents the ultraviolet and visible range, while the two others $([0.8-1.5]$ and $[1.5-2.8] \mu \mathrm{m})$ represent two near-infrared ranges. The total net shortwave radiation, $Q_{\mathrm{sn}}$, absorbed by the snow level $i$, is the sum of the absorption in each spectral band, $k$, and is given by

$$
\begin{aligned}
Q_{\mathrm{s}}(i)= & R_{\mathrm{sw}} \sum_{k=1}^{3}\left[\omega(k)\left(1-\alpha_{\mathrm{sn}}(k)\right)\right. \\
& \left.\exp \left(-\sum_{j=1}^{i}\left[\beta_{\mathrm{sn}}(k, j) \Delta z(j)\right]\right)\right],
\end{aligned}
$$

where $\omega$ is the empirical weight of each spectral band equal to $0.71,0.21$, and 0.08 for [0.3-0.8], [0.8-1.5] and [1.5$2.8] \mu \mathrm{m}$, respectively. As previously shown, the extinction coefficient of snow, $\beta_{\mathrm{sn}}$, depends on the density and optical diameter of snow. The snow albedo, $\alpha_{\mathrm{sn}}$, is a function of the snow optical diameter and of the age of the first layer of the snowpack. The age dependency is limited to the first band (visible range) and aims to represent the decrease of the snow albedo by impurities from deposition in a very simple way. Indeed, trace amount of light-absorbing impurities can significantly reduce snow albedo in the visible range but have no effect on the near-infrared range (Warren 1982). In each band, both the albedo and the extinction coefficient of snow are computed according to Brun et al. (1992) as follows:

$$
\begin{aligned}
& \alpha_{\mathrm{sn}}(1)=\max \left[0.6, \min \left(0.92,0.96-1.58 \sqrt{d_{\mathrm{opt}}(1)}\right)-\min \left(1, \max \left(\frac{1}{2}, \frac{P_{\mathrm{a}}}{P_{\mathrm{ref}}}\right)\right) \times 0.2 \frac{A_{\mathrm{sn}}(1)}{A_{\mathrm{ref}}}\right] \\
& \beta_{\mathrm{sn}}(1, i)=\max \left[40,0.00192 \rho_{\mathrm{s}}(i) / \sqrt{d_{\mathrm{opt}}(i)}\right] \\
& \alpha_{\mathrm{sn}}(2)=\max \left[0.3,0.9-15.4 \sqrt{d_{\mathrm{opt}}(1)}\right] \\
& \beta_{\mathrm{sn}}(2, i)=\max \left[100,0.01098 \rho_{\mathrm{s}}(i) / \sqrt{d_{\mathrm{opt}}(i)}\right] \\
& \alpha_{\mathrm{sn}}(3)=0.88+346.2 d^{\prime}-32.31 \sqrt{d^{\prime}} \text { with } d^{\prime}=\min \left[0.0023, d_{\mathrm{opt}}(i)\right] \\
& \beta_{\mathrm{sn}}(3, i)=+\infty
\end{aligned}
$$

where $A_{\mathrm{sn}}$ is the age of the first snow layer expressed in days, $A_{\text {ref }}$ a reference age set to 60 days that modulates the snow albedo decrease due to impurities, $P_{\mathrm{a}}(\mathrm{Pa})$ is the nearsurface atmospheric pressure, and $P_{\text {ref }}(\mathrm{Pa})$ a reference pressure equal to $870 \mathrm{hPa}$. The optical diameter of snow is simply given by Eq. (10) but is now also dependent on snow age:

$$
\begin{aligned}
d_{\mathrm{opt}}(i) & =\min \left[d_{\max }, g_{1}+g_{2} \times \rho_{\mathrm{sn}}(i)^{4}+g_{3}\right. \\
& \left.\times \min \left(15, A_{\mathrm{sn}}(i)\right)\right],
\end{aligned}
$$

where $g_{3}$ is the rate of increase of the optical diameter of snow with snow age. It is set to $0.5 \times 10^{-4} \mathrm{~m} \mathrm{day}^{-1}$ through calibration. The motivation to account for this snow age dependency on snow optical diameter is discussed in Sect. 6 .

The snow age for each layer is the time, in days, since the snow has fallen. When a snowfall event occurs, the fresh snow characteristics including its age ( 0 at time of snowfall) are averaged out with the snow already present in the first layer according to their respective masses. Finally, when the layer thicknesses of the entire snowpack are recalculated with Eqs. (11) and (12), the snow age is redistributed accordingly. Typically, the age of snow in the first shallower layers remains between 0 and approximately 2 weeks during winter and increases during spring, while the last deeper layers age continuously.

\subsection{Effects of soil organic carbon on soil hydraulic and thermal properties}

Northern Eurasian soils are rich in organic carbon, as shown in Fig. 1. This figure represents the soil organic carbon content of two soil horizons $(0-30$ and $30-70 \mathrm{~cm}$ ) aggregated at a $0.5^{\circ}$ by $0.5^{\circ}$ horizontal resolution and estimated from the Harmonized World Soil Database (HWSD; http://webarchive.iiasa.ac.at/ Research/LUC/External-World-soil-database/HTML/, FAO/IIASA/ISRIC/ISSCAS/JRC, 2012) at a $1 \mathrm{~km}$ resolution from the Food and Agricultural Organization (FAO/IIASA/ISRIC/ISSCAS/JRC, 2012). The parameterization of the impact of soil organic carbon on hydraulic and thermal properties in ISBA is based on pedotransfer functions of Boelter (1969), and on the work by Letts et al. (2000) and Lawrence and Slater (2008). The pedotransfer functions of Boelter (1969) link the soil water retention at different pressure levels to the fiber content of a peat soil. Letts et al. (2000) describe the vertical profile of hydraulic properties such as soil matric potential and hydraulic conductivity at saturation for a typical organic 


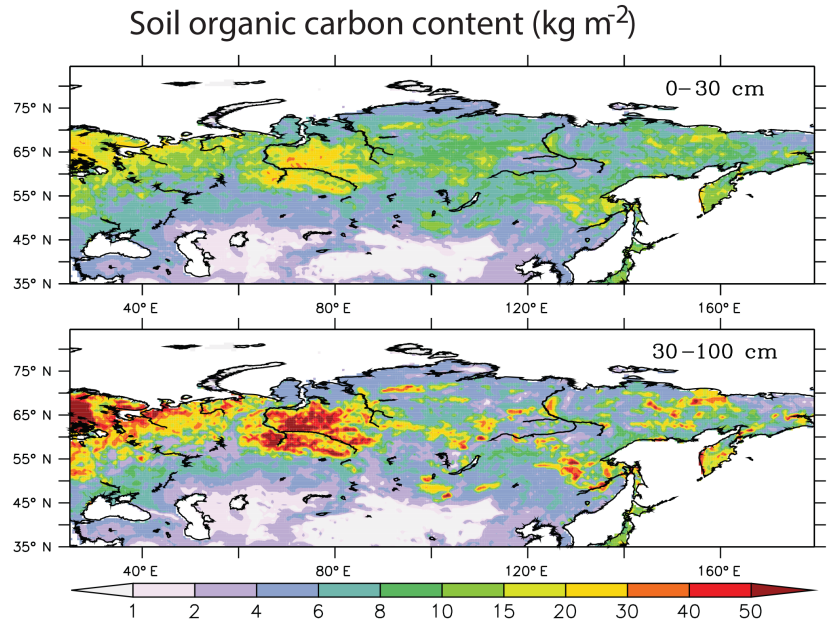

Figure 1. Spatial distribution of the observed soil organic carbon content over two soil horizon $(0-30$ and $30-70 \mathrm{~cm})$ at $0.5^{\circ}$ by $0.5^{\circ}$ resolution. Observations come from the Harmonized World Soil Database at $1 \mathrm{~km}$ resolution of the Food and Agricultural Organization.

soil. The hydraulic properties change sharply from the near surface where peat is weakly decomposed (fibric soil) to the subsurface with moderately and well decomposed peat (hemic and sapric soils respectively). Lawrence and Slater (2008) proposed a linear combination of such soil organic properties with the standard mineral soil properties.

In ISBA, before averaging soil organic properties with mineral properties, a typical peat soil profile is computed for the model soil grid using a power function for each hydraulic property, $\alpha_{\text {peat }}$, found in Table 1 . For each soil layer $i$, this function is described as

$\alpha_{\text {peat }}(i)=\alpha_{\text {fibric }} z(i)^{\beta}$ with $\beta=\frac{\ln \left(\alpha_{\text {sapric }} / \alpha_{\text {fibric }}\right)}{\ln \left(d_{\text {sapric }} / d_{\text {fibric }}\right)}$,

where $z(\mathrm{~m})$ is the depth of the considered soil grid node, $\alpha_{\text {fibric }}$ and $\alpha_{\text {sapric }}$ the fibric and sapric parameter values (Table 1$), d_{\text {fibric }}(\mathrm{m})$ the depth arbitrarily set to $0.01 \mathrm{~m}$ where the profile starts to depart from fibric values, and $d_{\text {sapric }}(\mathrm{m})$ the depth of $1 \mathrm{~m}$ where the soil properties reach the sapric values according to Letts et al. (2000).

To determine the organic fraction of soil, the density profile of the soil carbon must be known for the entire soil grid. Using the HWSD database, the soil carbon densities in the first $0.3 \mathrm{~m}, \rho_{\text {top }}\left(\mathrm{kg} \mathrm{m}^{-3}\right)$, and the remaining $0.7 \mathrm{~m}$ below, $\rho_{\text {sub }}\left(\mathrm{kg} \mathrm{m}^{-3}\right)$, are known:

$\rho_{\text {top }}=\frac{S_{\text {top }}}{\Delta d_{\text {top }}}$ and $\rho_{\text {sub }}=\frac{S_{\text {sub }}}{\Delta d_{\text {sub }}}$,

where $S_{\text {top }}$ and $S_{\text {sub }}\left(\mathrm{kg} \mathrm{m}^{-2}\right)$ are the topsoil and subsoil organic carbon contents respectively, $\Delta d_{\text {top }}$ and $\Delta d_{\text {sub }}$ (m) the thicknesses of each observed soil horizon $(0.3$ and $0.7 \mathrm{~m}$ respectively). We extrapolate the density present below $1 \mathrm{~m}$ from this observed near-surface profile (Eq. 20). The extrapolation assumes that the carbon profile decreases sharply with soil depth according to a power function. The shape of this function is given by the observed profile if the topsoil organic carbon density is superior to the subsoil density. Otherwise, the density of soil carbon below a $1 \mathrm{~m}$ depth, $\rho_{\text {deep }}\left(\mathrm{kg} \mathrm{m}^{-3}\right)$, is taken to be equal to the subsoil density:

$$
\mid \begin{aligned}
& \rho_{\text {deep }}=(1-\delta) \rho_{\text {sub }}+\delta \frac{s_{\text {top }}+s_{\text {sub }}}{\Delta d_{\text {deep }}-\Delta d_{\text {top }}-\Delta d_{\text {sub }}}\left[\left(\frac{\Delta d_{\text {deep }}}{\Delta d_{\text {top }}+\Delta d_{\text {sub }}}\right)^{\beta}-1\right] \\
& \delta=\left\{\begin{array}{ll}
0 & \forall \rho_{\text {top }} \leq \rho_{\text {sub }} \\
1 & \forall \rho_{\text {top }}>\rho_{\text {sub }}
\end{array} \text { and } \beta=\frac{\ln \left[s_{\text {top }} /\left(s_{\text {top }}+s_{\text {sub }}\right)\right]}{\ln \left[\Delta d_{\text {top }} /\left(\Delta d_{\text {top }}+\Delta d_{\text {sub }}\right)\right]}\right.
\end{aligned},
$$

where $\Delta d_{\text {deep }}(\mathrm{m})$ is an infinite soil thickness taken to be arbitrarily equal to $1000 \mathrm{~m}$.

Finally, the soil carbon density profile, $\rho_{\text {soc }}\left(\mathrm{kg} \mathrm{m}^{-3}\right)$, over the entire soil grid is computed using these three soil horizons and a simple linear interpolation at each grid node that conserves the total soil carbon mass (Fig. 2). The fraction of the soil that is organic, $f_{\text {soc }}$, in each layer is determined assuming this simple relationship:

$$
f_{\text {soc }}(i)=\frac{\rho_{\text {soc }}(i)}{\left(1-w_{\text {sat,peat }}(i)\right) \rho_{\text {om }}},
$$

where $\rho_{\mathrm{om}}\left(\mathrm{kg} \mathrm{m}^{-3}\right)$ is the pure organic matter density equal to $1300 \mathrm{~kg} \mathrm{~m}^{-3}$ (Farouki, 1986) and $w_{\text {sat,peat }}$ the porosity of the peat soil profile computed using Eq. (19) and Table 1. As in Lawrence and Slater (2008), this fraction is used to combine the standard mineral soil properties with soil organic properties using weighted arithmetic or geometric averages, depending on the parameter (Table 1). An example of this method is shown in Fig. 2 for soil porosity, soil saturated hydraulic conductivity, and soil heat capacity.

\section{Local-scale evaluation of snow processes at the Col de Porte site (France)}

\subsection{Experimental data set}

The Col de Porte field site $\left(45^{\circ} 17^{\prime} \mathrm{N}, 05^{\circ} 45^{\prime} \mathrm{E}\right)$ is located at an elevation of $1325 \mathrm{~m}$ in the French Alps near Grenoble (Morin et al., 2012). It consists of a $50 \mathrm{~m}$ by $50 \mathrm{~m}$ square covered by grass, mowed approximately once a month in summer depending on its growth rate. Soil textures (30\% clay, $60 \%$ sand) are characteristic of a sandy clay loam soil that is very poor in organic carbon. For this reason, this site is only used to evaluate the effect of changes in snow parameterizations, while changes in soil physics cannot be tested. The atmospheric forcing variables (air temperature, rain and snow rates, air humidity, atmospheric pressure, wind speed, longwave and shortwave incident radiation) are available at a $1 \mathrm{~h}$ time step from 1 August 1993 to 31 July 2011. It consists of a combination of in situ measurements, roughly from September to June each year, and the regional reanalysis SAFRAN 
Table 1. The peat soil hydraulic and thermal parameter values used in ISBA for fibric and sapric soil. $w_{\mathrm{sat}}\left(\mathrm{m}^{3} \mathrm{~m}^{-3}\right)$ is the porosity, $w_{\mathrm{fc}}$ $\left(\mathrm{m}^{3} \mathrm{~m}^{-3}\right)$ the water content at field capacity specified as matric potential at -0.1 bar for peat soil, $w_{\text {wilt }}\left(\mathrm{m}^{3} \mathrm{~m}^{-3}\right)$ the water content at wilting point (matric potential of $-15 \mathrm{bar}), b$ the dimensionless shape parameter of the soil water retention curve, $\psi_{\text {sat }}(\mathrm{m})$ the soil matric potential, $k_{\mathrm{sat}}\left(\mathrm{m} \mathrm{s}^{-1}\right)$ the soil hydraulic conductivity at saturation, $c\left(\mathrm{~J} \mathrm{~m}^{-3} \mathrm{~K}^{-1}\right)$ the soil heat capacity of organic matter, $\lambda_{\mathrm{s}}\left(\mathrm{W} \mathrm{m}{ }^{-1} \mathrm{~K}^{-1}\right)$ the thermal conductivity of soil matrix, and $\lambda_{\text {dry }}\left(\mathrm{W} \mathrm{m}^{-1} \mathrm{~K}^{-1}\right)$ the dry soil thermal conductivity. For pedotransfer functions of Boelter (1969), the fiber content in fibric soil is assumed to be equal to $76.8 \%$ against $21.8 \%$ in sapric soil in order to reach soil porosity values close to Letts et al. (2000). The method for averaging mineral soil properties with peat soil values using the fraction of soil that is organic is also given for each parameter.

\begin{tabular}{lllll}
\hline$\alpha_{\text {peat }}$ & $\begin{array}{l}\text { Fibric } \\
\text { soil }\end{array}$ & $\begin{array}{l}\text { Sapric } \\
\text { soil }\end{array}$ & Sources & $\begin{array}{l}\text { Mineral/peat } \\
\text { average }\end{array}$ \\
\hline$w_{\text {sat }}$ & 0.930 & 0.845 & Letts et al. (2000) and Boelter (1969) & Arithmetic \\
$w_{\text {fc }}$ & 0.369 & 0.719 & PTF from Boelter (1969) & Arithmetic \\
$w_{\text {wilt }}$ & 0.073 & 0.222 & PTF from Boelter (1969) & Arithmetic \\
$b$ & 2.7 & 12 & Letts et al. (2000) & Arithmetic \\
$\psi_{\text {sat }}$ & -0.0103 & -0.0101 & Letts et al. (2000) & Arithmetic \\
$k_{\text {sat }}$ & $2.8 \times 10^{-4}$ & $1.0 \times 10^{-7}$ & Letts et al. (2000) & Geometric \\
$c$ & $2.5 \times 10^{-6}$ & $2.5 \times 10^{-6}$ & Farouki (1986) & Arithmetic \\
$\lambda_{\mathrm{s}}$ & 0.25 & 0.25 & Farouki (1986) & Geometric \\
$\lambda_{\text {dry }}$ & 0.05 & 0.05 & Farouki (1986) & Geometric \\
\hline
\end{tabular}
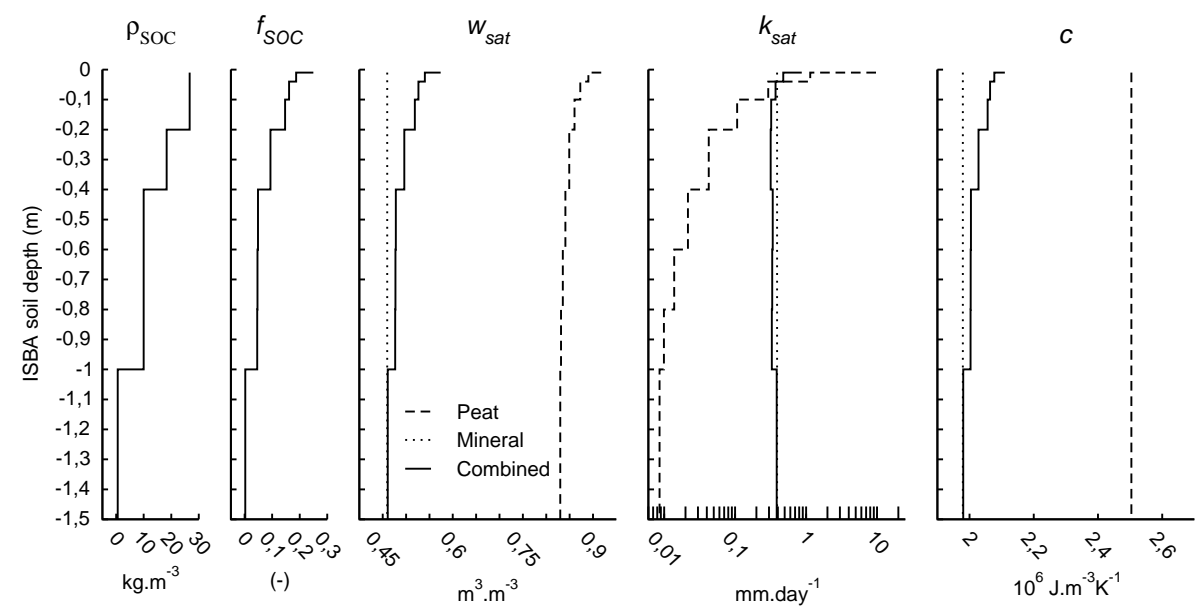

Figure 2. Parameterization of the effect of soil organic carbon (SOC) on soil hydraulic and thermal properties. The soil organic carbon density profile, $\rho_{\text {soc }}$, is given by Eq. (21) using a top soil organic carbon content of $10 \mathrm{~kg} \mathrm{~m}^{-2}$, a subsoil content of $15 \mathrm{~kg} \mathrm{~m}{ }^{-2}$, and via a simple linear interpolation at each soil grid nodes that conserves the total soil carbon mass. The fraction of the soil that is organic, $f_{\text {soc }}$, in each layer is determined assuming a simple relationship between this last soil organic carbon density profile and an idealized peat soil density profile (Eq. 22). Examples for the soil porosity, $w_{\text {sat }}$, the soil saturated hydraulic conductivity, $k_{\text {sat }}$, and the soil heat capacity, $c$, are given. Dotted lines represent vertical homogeneous mineral soil properties, dashed lines the idealized peat soil properties, and plain lines the resulting combined soil properties using the averaging method summed up in Table 1.

from June to September each year (see Morin et al. (2012) for details).

The Col de Porte data set includes many observations at a daily time step for evaluating land surface models. In this study, the observed snow depth, surface albedo, and soil temperature at $10 \mathrm{~cm}$ are used to evaluate model simulations over the entire period. The snow water equivalent (SWE) is also used for this model evaluation but daily values are only available from 2001 to 2011. Snow depth is measured using ultrasound depth gauges with an accuracy of $1 \mathrm{~cm}$. Surface albedo is computed as the total daily reflected solar flux divided by the total daily incoming solar flux. We estimate the uncertainty in surface albedo to be about $10 \%$ based on the $10 \%$ uncertainty in observed radiative fluxes reported by Morin et al. (2012). Soil temperature is measured using automatic probes with an accuracy of $0.1 \mathrm{~K}$. SWE is measured using a cosmic ray sensor placed on the ground and exhibits an uncertainty of $10 \%$. Three skill scores are used to compare model results to the observations. The mean annual bias measures the capability of the model to represents the observed 
mean. To evaluate the model ability to represent the observed day to day variability, two statistical quantities are used: the square correlation $\left(r^{2}\right)$, and the centered root mean square error (c-rmse). It is computed by subtracting the simulated and observed annual means from their respective time series before computing a standard root mean square error.

\subsection{Model configuration}

Four simulations were carried out to evaluate the effect of the different changes in the snow parameterization detailed in Sect. 3.

- The control simulation, named CTL, uses Boone and Etchevers' (2001) formulation for snow layering (three layers), snow compaction, and snow albedo as described in Sect. 2.2.

- The second simulation, SNL, is similar to CTL in terms of snow compaction and albedo but uses the new snow layering with 12 snow layers described in Sect. 3.1.1.

- The third simulation, CPT, uses 12 snow layers as in SNL but the compaction and the wind-induced densification of near-surface snow layers are computed using formulations of Brun et al. $(1989,1997)$, both described in Sect. 3.1.2.

- The last simulation, NEW, uses all the package of snow equations described in Sect. 3.1: 12 snow layers, the new snow compaction/densification, but also the spectral representation of the snow albedo (Sect. 3.1.3).

For all of the simulations, the snow is assumed to cover the entire grid cell (the snow fraction set to (1) as long as the snow remains present. The effective roughness length of snow is set to its usual value of $0.001 \mathrm{~m}$. The grid cell is assumed to be entirely covered by grass with a root depth of $1 \mathrm{~m}$, the leaf area index varies from 0.1 in winter to 1 in summer, and the snow-free surface albedo is prescribed as 0.2. The model calculates soil temperature, moisture, and ice content in each of the 14 soil layers corresponding to a soil depth of $12 \mathrm{~m}$. The model was run with a $15 \mathrm{~min}$ time step from 1 August 1993 to 31 July 2011. The model was spun-up by performing 50 iterations of the first 2 years (August 1993 to July 1995). This spin-up represents a total of 100 years, and this was determined to guarantee that the water and heat profiles were equilibrated over the $12 \mathrm{~m}$ soil depth of ISBA. Results are then evaluated over the entire period.

\subsection{Results}

Figures 3 and 4 show an overview of the four simulations performed at the Col de Porte in terms of snow depth, SWE, surface albedo, and soil temperature at $10 \mathrm{~cm}$. A quick look at the time series indicates that all of the model versions match the observations relatively well. However, an- nual statistics show a clear hierarchy between the four experiments. The snow depth statistics show that the new snow compaction/densification algorithm has a positive impact on the snowpack simulation. Indeed, both the CPT and NEW experiments exhibit the lowest bias and c-rmse for 12 of the 18 years. However, the comparison to SWE data does not allow a discrimination between the four simulations, even if the c-rmse of the NEW experiment is the best for 7 of the 10 years. The surface albedo from the NEW simulation is clearly better than the albedo from the other experiments; bias and c-rmse are the best for all years (Fig. 4). The soil temperature bias and c-rmse are also reduced by the NEW experiment (for 10 of 17 years) compared to the other simulations. Thus, accounting for different spectral bands within the snow albedo calculation has a significant positive impact on the energy balance of the snow-soil system.

The average seasonal cycle of snow depth, SWE, surface albedo, and soil temperature at $10 \mathrm{~cm}$ represented in Fig. 5 highlights the qualities and weaknesses of the different parameterizations by focusing on the snow season (October to May). The corresponding statistics for the winter (DJF), spring (MAM), and the entire period are given in Table 2. The comparison of SNL to CTL indicates that the increase in number of snow layers from 3 to 12 improves the snow depth, SWE, and winter soil temperature simulation. Change in snow compaction (from SNL to CPT) improves the seasonal cycle of snow depth and SWE and especially the maximum value. The seasonal and total biases in Table 2 verify this result and show the same behavior for winter soil temperature, although it is difficult to see visually from Fig. 5. For these three variables, the simulated time variability is also improved from CTL to SNL to CPT, as shown by the other seasonal and total scores (c-rmse and $r^{2}$ ) in Table 2. Finally, the new spectral albedo scheme (from CPT to NEW) has a drastic impact on the snowpack simulation in spring. As shown by Fig. 5 and Table 2, the new spectral albedos clearly improve the simulation of other variables during this period. They induce a sharp springtime snowmelt with a strong decrease in snow depth and SWE. The snow insulation during spring is thus less important and allows the soil surface to warm up faster. As a result, the model is capable of reproducing the strong soil warming observed in April (Fig. 5). Not surprisingly, the soil temperature skill scores for spring and the whole period are drastically improved, although there is a slight degradation in winter.

Figure 6 shows daily mean time series of the snow density and temperature profiles averaged over the snow season for each experiment. With only three snow layers (CTL), the density distribution is more uniform than using the new snow layering scheme with 12 layers (SNL). The significant densification of the bottom layers in SNL is the main process responsible for the snow depth and SWE improvements observed in Fig. 5 and Table 2. In addition, the better representation of the vertical density profile, that results in less dense and thus more insulating surface snow layers from Novem- 

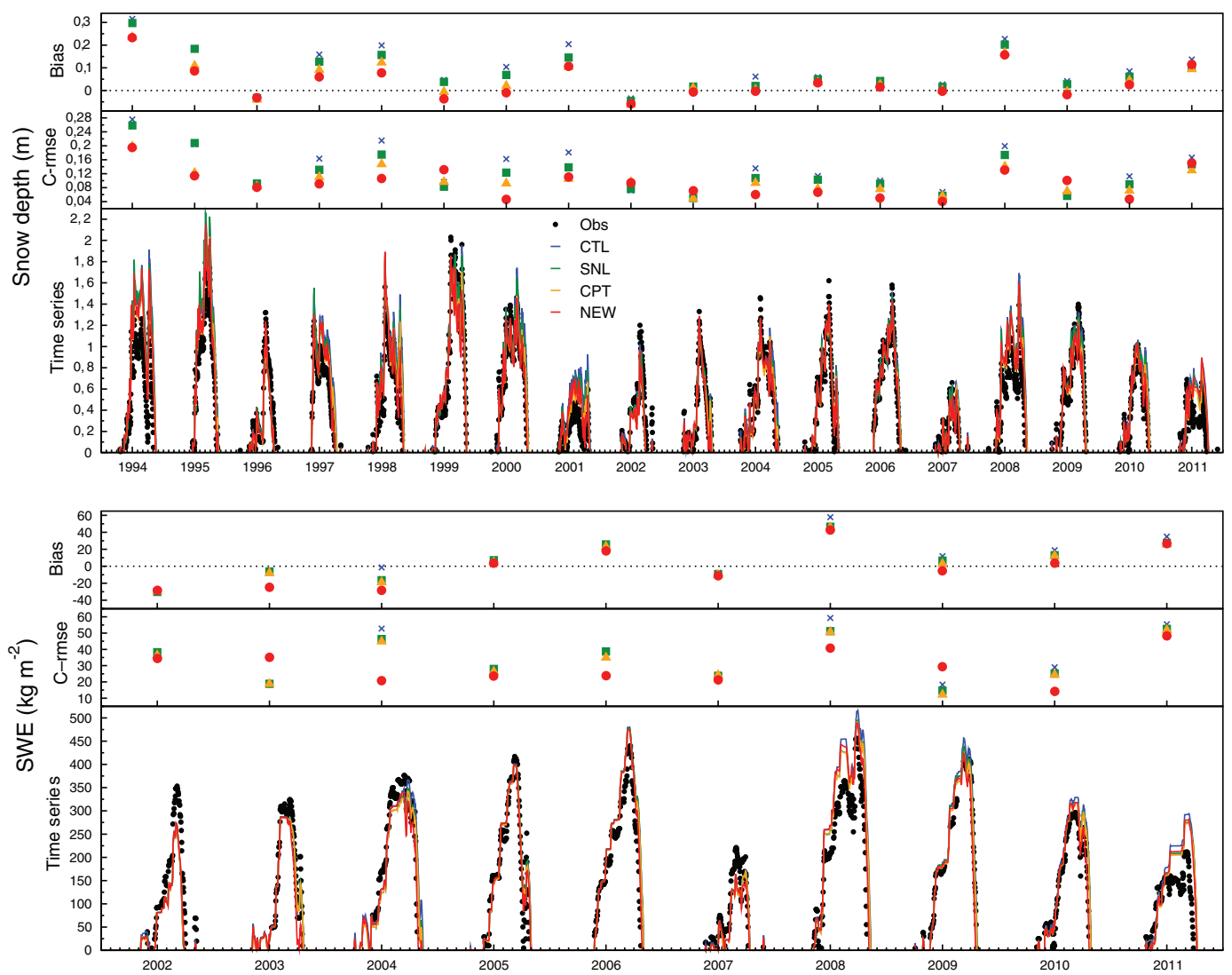

Figure 3. Overview of the four experiments performed at the Col de Porte field site. Daily simulated and observed data for snow depth (top panel) and SWE (bottom panel) are provided for 18 and 10 years respectively. In situ observations are in black, the CTL simulation in blue, SNL in green, CPT in orange, and NEW in red. The corresponding statistics are given in terms of annual bias and c-rmse for each year by measurements periods.

ber to February, leads to a better insulation of the bottom snow layer from the atmosphere and thus to higher temperatures of the bottom snow and top soil layers. This explains the skill scores improvement found in winter soil temperature in Table 2. The new snow compaction scheme (CPT) tends to increase the density contrast between the top and the bottom snow layers. The snowpack is also denser than with SNL, leading to the strong decrease in snow depth observed in Fig. 5 and to the better skill scores in snow depth over each period (Table 2).

CPT also results in a small warming at the bottom of the snowpack which slightly heats the soil temperature compared to SNL. Finally, the spectral albedo scheme (NEW) has a limited effect on the snow density profile but results in a slightly colder snowpack than in CPT and even SNL (not shown) due to the large daily winter albedos seen in Fig. 5. This is the main reason for the lower winter soil temperatures with NEW than CPT and SNL (Table 2).

\section{Simulations over northern Eurasia}

\subsection{Numerical experiment design and observational data set}

The experimental design used here is close to that proposed by Brun et al. (2013). The region considered ( 35 to $85^{\circ} \mathrm{N}, 25$ to $180^{\circ} \mathrm{E}$ ) covers eastern Europe, Russia, and Siberia (Fig. 7). The ISBA land surface model is run at a $0.5^{\circ}$ by $0.5^{\circ}$ spatial resolution using the Interim Reanalysis (ERA-I; http://www.ecmwf.int/en/research/ climate-reanalysis/era-interim, Dee et al., 2011). ERA-I meteorological variables are extracted with a 3-hourly frequency in order to represent the diurnal cycle. This reanalysis covers the time period from 1979 to the present. Many details about ERA-I can be found in Dee et al. (2011) and an evaluation of its performance is provided in Berrisford et al. (2011). For precipitation, the monthly ERA-I precipitation values are rescaled to match the observed Global Precipitation Climatology Center (GPCC) Full Data Product V5 (http://gpcc.dwd.de, Schneider et al., 2006) as proposed by Decharme and Douville (2006a). This method conserves the 

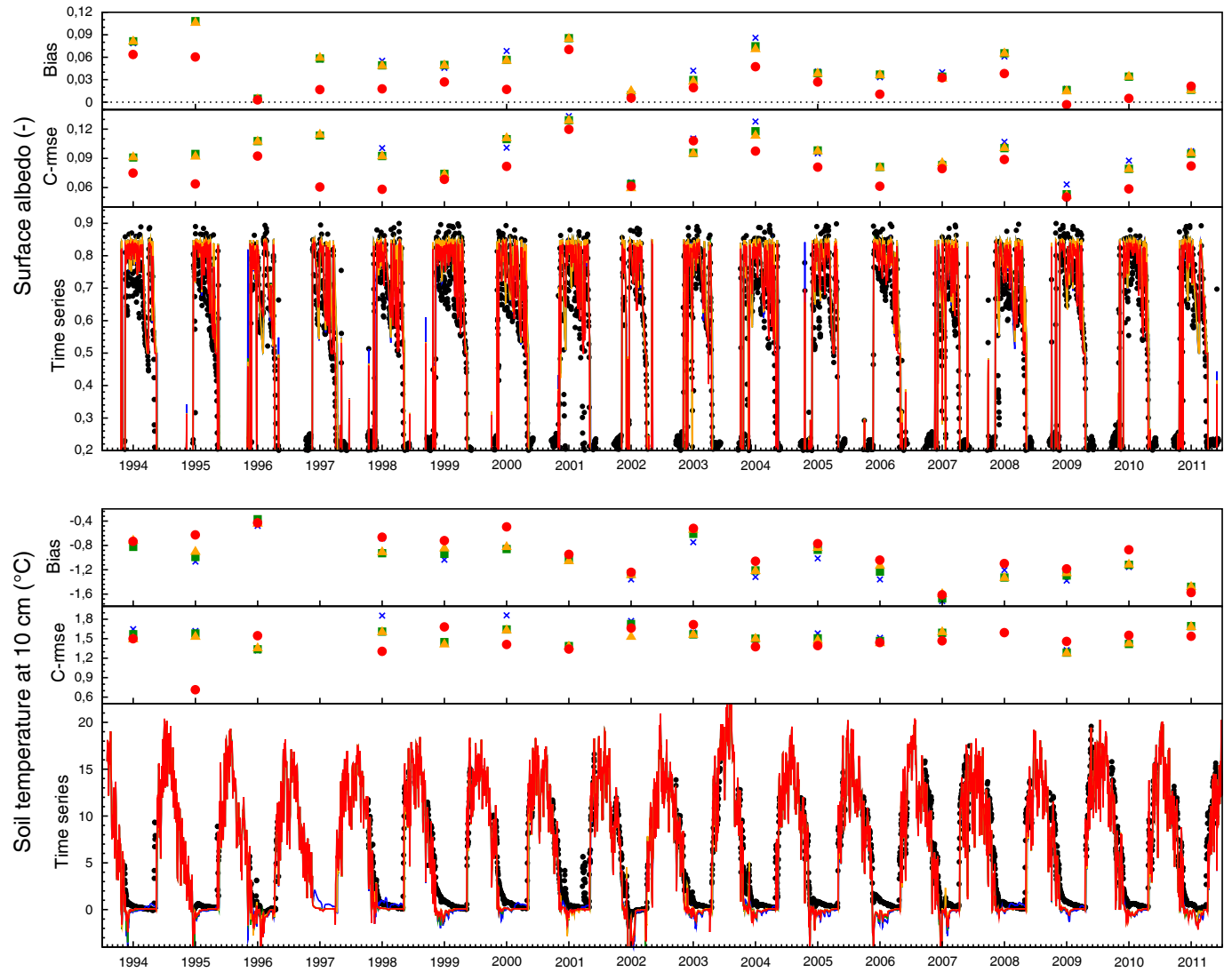

Figure 4. As Fig. 3 but for surface albedo (top panel) and soil temperature at $10 \mathrm{~cm}$ depth (bottom panel).
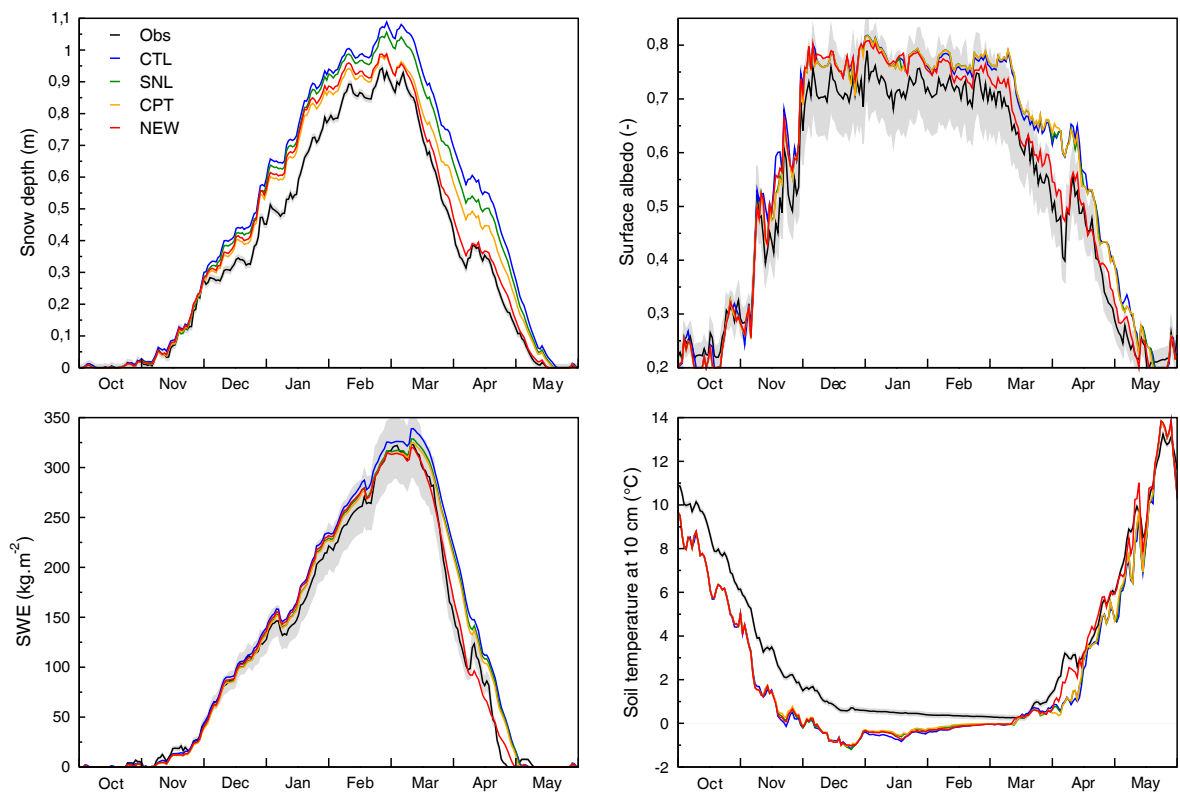

Figure 5. Daily mean annual cycles of snow depth, SWE, surface albedo, and soil temperature at $10 \mathrm{~cm}$ depth simulated (colors) and observed (black) at the Col de Porte field site. The corresponding skill scores are given in Table 2. Over all panels, the grey shadow corresponds to the uncertainty in in situ measurements as discussed in Sect. 4.1. The observed snow depth exhibits an accuracy of $\pm 1 \mathrm{~cm}$, the soil temperature is measured with a precision of $\pm 1 \mathrm{~K}$, while uncertainties in SWE and surface albedo are near $\pm 10 \%$. 

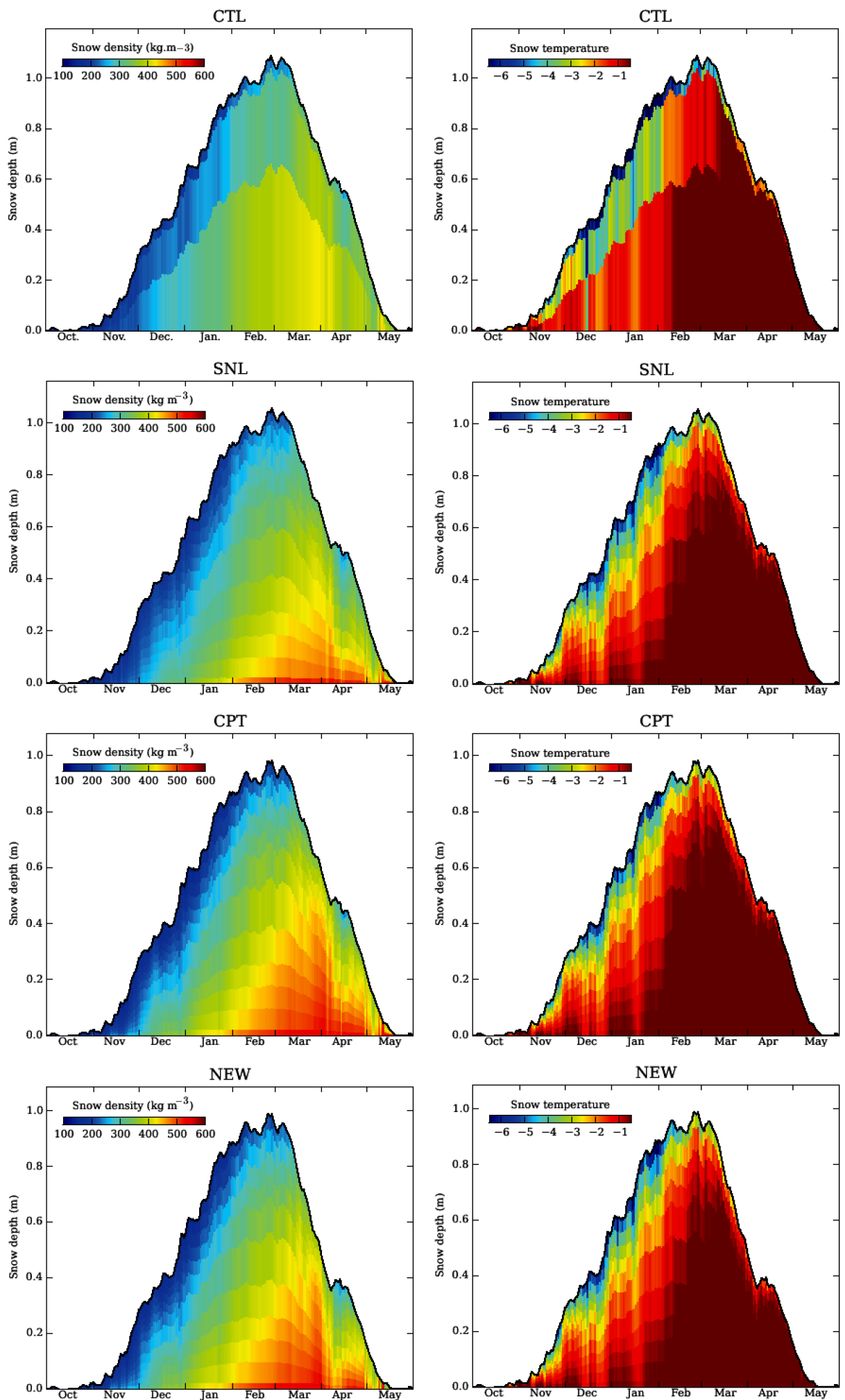

Figure 6. Daily mean annual cycles of snow density $\left(\mathrm{kg} \mathrm{m}^{-3}\right)$ and snowpack internal temperature $\left({ }^{\circ} \mathrm{C}\right)$ simulated by the four experiments over 18 years at the Col de Porte field site. 
Table 2. Daily skill scores simulated by each experiment at Col de Porte for snow depth, SWE, albedo, and soil temperature at $10 \mathrm{~cm}$ over the number of point measurement, $n$. The bias, centered root mean square error (c-rmse) and square correlation $\left(r^{2}\right)$ described in Sect. 4.1 are shown. The best scores are given in bold.

\begin{tabular}{|c|c|c|c|c|c|}
\hline \multirow[t]{2}{*}{ Period } & \multirow[t]{2}{*}{ Criterion } & \multicolumn{4}{|c|}{ Experiments } \\
\hline & & CTL & SNL & CPT & NEW \\
\hline \multicolumn{6}{|c|}{ Snow depth (m) } \\
\hline DJF & bias & 0.126 & 0.108 & 0.074 & 0.089 \\
\hline \multirow[t]{2}{*}{$(n=1624)$} & c-rmse & 0.159 & 0.157 & 0.126 & 0.130 \\
\hline & $r^{2}$ & 0.863 & 0.870 & 0.907 & 0.900 \\
\hline \multirow[t]{3}{*}{ MAM $(n=1656)$} & bias & 0.165 & 0.127 & 0.077 & 0.027 \\
\hline & c-rmse & 0.223 & 0.192 & 0.169 & 0.155 \\
\hline & $r^{2}$ & 0.845 & 0.878 & 0.884 & 0.900 \\
\hline All & bias & 0.102 & 0.082 & 0.053 & 0.041 \\
\hline \multirow[t]{2}{*}{$(n=4737)$} & c-rmse & 0.176 & 0.157 & 0.130 & 0.126 \\
\hline & $r^{2}$ & 0.889 & 0.908 & 0.923 & 0.927 \\
\hline \multicolumn{6}{|c|}{$\operatorname{SWE}\left(\mathrm{kg} \mathrm{m}^{-2}\right)$} \\
\hline DJF & bias & 12.329 & 6.196 & 4.934 & 8.887 \\
\hline \multirow[t]{2}{*}{$(n=835)$} & c-rmse & 38.331 & 35.004 & 34.476 & 36.079 \\
\hline & $r^{2}$ & 0.901 & 0.913 & 0.915 & 0.911 \\
\hline MAM & bias & 25.022 & 19.064 & 16.352 & 0.334 \\
\hline \multirow[t]{2}{*}{$(n=887)$} & c-rmse & 61.138 & 57.204 & 55.699 & 49.583 \\
\hline & $r^{2}$ & 0.861 & 0.872 & 0.876 & 0.900 \\
\hline All & bias & 13.851 & 9.169 & 7.648 & 2.981 \\
\hline \multirow{2}{*}{$(n=2310)$} & c-rmse & 45.641 & 42.267 & 41.134 & 38.100 \\
\hline & $r^{2}$ & 0.902 & 0.910 & 0.913 & 0.924 \\
\hline \multicolumn{6}{|c|}{ Albedo (-) } \\
\hline DJF & bias & 0.047 & 0.047 & 0.047 & 0.045 \\
\hline \multirow{2}{*}{$(n=1456)$} & c-rmse & 0.076 & 0.076 & 0.076 & 0.074 \\
\hline & $r^{2}$ & 0.528 & 0.535 & 0.533 & 0.506 \\
\hline MAM & bias & 0.077 & 0.077 & 0.076 & 0.023 \\
\hline \multirow[t]{2}{*}{$(n=1516)$} & c-rmse & 0.119 & 0.117 & 0.115 & 0.080 \\
\hline & $r^{2}$ & 0.768 & 0.785 & 0.792 & 0.889 \\
\hline All & bias & 0.048 & 0.046 & 0.045 & 0.026 \\
\hline \multirow{2}{*}{$(n=4101)$} & c-rmse & 0.101 & 0.098 & 0.098 & 0.082 \\
\hline & $r^{2}$ & 0.858 & 0.869 & 0.871 & 0.905 \\
\hline \multicolumn{6}{|c|}{ Soil temperature $10 \mathrm{~cm}(\mathrm{~K})$} \\
\hline DJF & bias & -1.082 & -1.009 & -0.962 & -1.032 \\
\hline \multirow[t]{2}{*}{$(n=1323)$} & c-rmse & 0.892 & 0.837 & 0.797 & 0.811 \\
\hline & $r^{2}$ & 0.234 & 0.234 & 0.272 & 0.279 \\
\hline MAM & bias & -0.646 & -0.624 & -0.606 & -0.199 \\
\hline \multirow[t]{2}{*}{$(n=838)$} & c-rmse & 2.109 & 1.995 & 1.967 & 1.701 \\
\hline & $r^{2}$ & 0.827 & 0.848 & 0.852 & 0.896 \\
\hline & bias & -1.121 & -1.079 & -1.049 & -0.936 \\
\hline \multirow{2}{*}{$(n=2237)$} & c-rmse & 1.650 & 1.591 & 1.569 & 1.519 \\
\hline & $r^{2}$ & 0.871 & 0.880 & 0.883 & 0.894 \\
\hline
\end{tabular}

3-hourly chronology of the ERA-I precipitation but ensures a reasonable monthly amount (Szczypta et al., 2012). Brun et al. (2013) pointed out the significantly better performance of this ERA-I-scaled GPCC forcing product in simulating northern Eurasian snowpack variables compared to the ERAI precipitation or other state-of-the-art global-scale atmospheric forcings.

To evaluate snow and soil temperature simulations, several in situ data sets are used. As in Brun et al. (2013), the His- torical Soviet Daily Snow Depth (HSDSD; http://nsidc.org/ data/docs/noaa/g01092_hsdsd/index.html, Armstrong, 2001) compiled by Amstrong (2001) was used in the current study. It consists of daily snow depth measurements taken at synoptic stations following the World Meteorological Organization (WMO) standards. WMO requires the measurements to be taken in bare ground open areas or clearings with regular grass cutting. These snow depth data are therefore representative of open areas of bare ground or those covered with very short grass. This data set starts in 1881 with a few stations and ends in 1995. Considering that ERA-I starts in 1979, the model simulations are done from 1979 according to Brun et al. (2013). 263 HSDSD stations are available over this period with approximately half of them without any missing data. We chose to use only the stations where the difference between the local and the ERA-I elevation is less than $100 \mathrm{~m}$, to avoid temperature biases for instance that would be directly due to the low resolution of ERA-I. We also only kept the stations where the number of days with a nonzero snow depth measurement over the entire period is superior to 100 days, and that have at least 8 days with snow measurement per year. With this filter, the number of available stations decreases to 158 , which remains acceptable. Most stations are located in Russia and western Siberia with only a few in eastern Siberia (Fig. 7).

The second source of observations is the Russian Historical Soil Temperature (RHST) data set compiled by Zhang et al. (2001) over Siberia (http://data.eol.ucar.edu/codiac/dss/ id=106.ARCSS078, Zhang et al., 2001). Data coverage extends from the 1800s through 1990, but is not continuous. We compared our model results over the 1979-1990 period. Similar to snow depth, soil temperature stations are subject to WMO standards and are located in open area sites. We used the same criteria as for snow depth. Only stations with local elevations close to the ERA-I altitude (less than $100 \mathrm{~m}$ difference) are used. In addition, only stations with at least 36 months of observations (at least 3 years out of 12) are kept. Most soil temperature sites are collocated with snow depth sites (Fig. 7). Measurements were taken at depths of $20,80,160$, and $320 \mathrm{~cm}$. For each depth, 95, 48, 48, and 82 stations, respectively, were available for model evaluation. The spatial distribution of these stations is shown in Fig. 7 for depths of 20 and $160 \mathrm{~cm}$.

To quantify the capability of the model to simulate the permafrost characteristics, three data sets are used. The first data set is the Circum-Arctic map of permafrost and ground ice conditions (http://nsidc.org/data/ggd318, Brown et al., 2002) edited by Brown et al. (2002). This data set is available at a $0.5^{\circ}$ by $0.5^{\circ}$ resolution and shows the continuous, discontinuous, isolated, and sporadic permafrost boundaries. The second data set gives access to in situ observations on active layer thickness collected by the Circumpolar Active Layer Monitoring network (CALM; http://www.gwu.edu/ calm/, Brown et al., 2000) from the 1990s to 2015 (Brown et al., 2000). Over the studied domain, 233 monitoring sites 

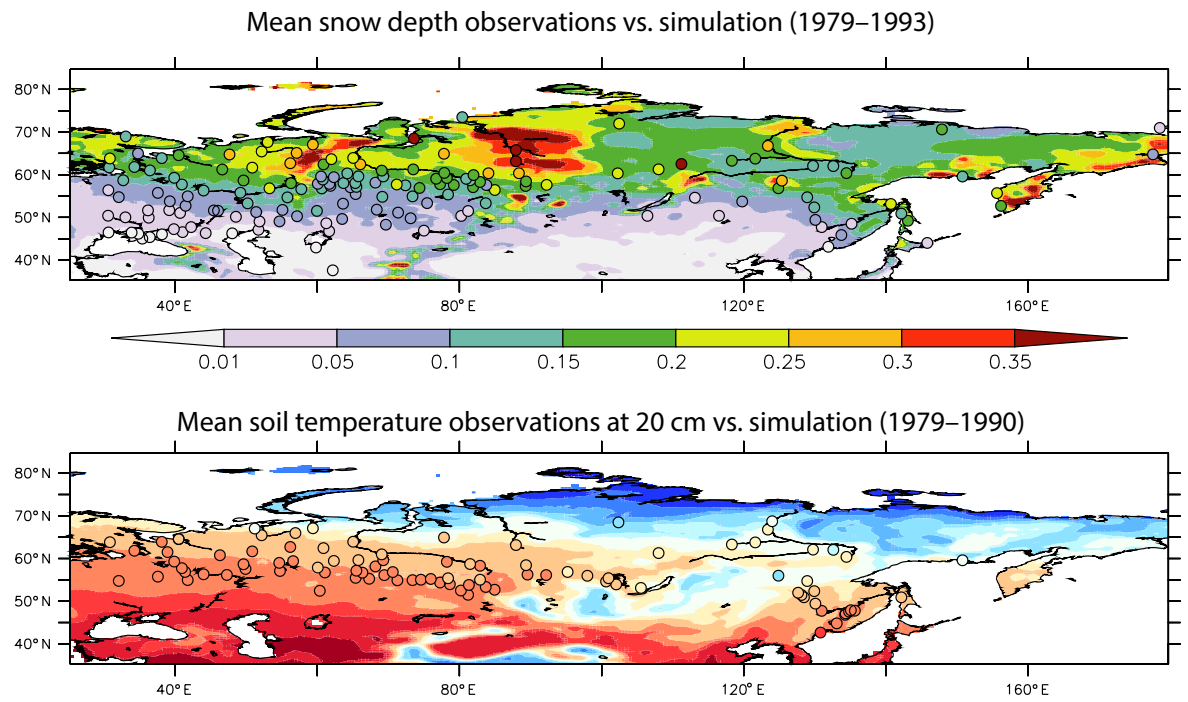

Mean soil temperature observations at $160 \mathrm{~cm}$ vs. simulation (1979-1990)

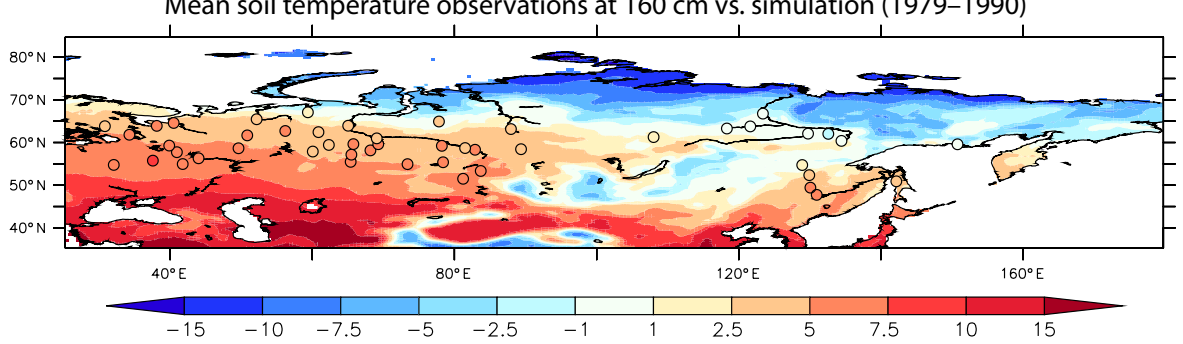

Figure 7. Quantitative comparison between observed (plain circles) and simulated (plain fields) daily snow depth and monthly soil temperature at 20 and $160 \mathrm{~cm}$ depths over northern Eurasia. Only the results from the bare soil sub-grid patch of the NEW-SOC simulation are presented because in situ measurements have been collected in open areas following the WMO standards as mentioned in Sect. 5.1.

are available. To compare with simulations performed at a $0.5^{\circ}$ by $0.5^{\circ}$ resolution, 89 virtual stations have been computed from the 233 original sites by averaging all stations in each $0.5^{\circ}$ by $0.5^{\circ}$ grid cells. The last data set is an estimate of the active layer thickness over northwest Siberia before the 1990s. This data set is based on the map of landscapes and permafrost conditions in Yakutia (Beer et al., 2013; doi:10.1594/PANGAEA.808240). It gives access to the mean and standard deviation of the most probable active layer thickness in each grid box at $0.5^{\circ}$ by $0.5^{\circ}$ resolution. All details can be found in Beer et al. (2013).

\subsection{Model configuration}

Three experiments using the ISBA land surface model forced by the ERA-I-scaled GPCC atmospheric data set are performed using the same configuration. In addition to the CTL (old snow scheme) and NEW (new snow scheme) experiments already described in Sect. 4, we performed one simulation using the parameterization of the impact of the soil organic carbon on the hydrologic and thermal soil properties. This last experiment, called NEW-SOC (soil organic carbon), uses the new snow and soil property schemes described in Sects. 3.1 and 3.2, respectively. As previously done, the model determines the temperature, liquid water, and ice content evolution in each of the 14 soil layers corresponding to a total soil depth of $12 \mathrm{~m}$. The model is run with a $15 \mathrm{~min}$ time step from 1 January 1979 to 31 December 2013. The model's spin-up uses 20 iterations of the first 5 years (1979 to 1983) of the atmospheric forcing, representing a total of 100 years.

In ISBA, we use a series of 12 sub-grid independent patches per grid cell in order to account for land cover heterogeneity. Land cover parameters such as the leaf area index (LAI), vegetation height, vegetation/soil albedos, and rooting depth are prescribed for each sub-grid patch. The dominant patches present in the model over the northern Eurasian region are bare soil, grassland/tundra, deciduous forest, coniferous boreal forest, and C3 crops in the south. The fraction of each surface type within each grid box is used to compute the grid box average of the water and energy budgets. Some other processes, such as surface runoff, dripping from the canopy reservoir, and soil infiltration, account for sub-grid parameterizations. More details can be found in Decharme and Douville (2006b) and Decharme et al. (2013).

For all of the simulations, the grid-cell fraction covered by snow evolves according to the simulated snow depth and is different for bare soil and vegetated areas (Appendix C) 
in each land cover patch. As was the case for the Col de Porte experiment, the effective roughness length of snow retains its usual value of $0.001 \mathrm{~m}$. The land surface parameters used by ISBA are specified according to the $1 \mathrm{~km}$ resolution ECOCLIMAP-II database (Faroux et al., 2013). LAI, vegetation height, and vegetation/soil albedos are prescribed for the 12 vegetation sub-grid patches based on a mean annual cycle at a 10-day time step. The rooting depth is specified for each vegetation type according to Canadell et al. (1996). It ranges from 0.5 to $1.5 \mathrm{~m}$ for tundra and temperate grassland, and from 2 to $3 \mathrm{~m}$ for forest. The soil textural properties are given by the HWSD database at $1 \mathrm{~km}$ resolution, while the topographic information is specified according to the 30 arcsecond resolution GTOPO30 data set.

\subsection{Results}

Figure 7 presents a quantitative comparison between the observed and simulated snow depth and soil temperature over northern Eurasia. Because in situ observations were collected in bare ground open areas and/or clearings with regular grass cutting following the WMO standards as mentioned previously, they are compared to snow depths and soil temperature profiles simulated by the ISBA bare soil sub-grid patch alone. This patch exhibits conditions which are closest to those at the corresponding field sites, as is generally the case for ISBA in this kind of comparison (Decharme et al., 2013). The simulation represented here is the NEW-SOC experiment that seems to capture well the snow depth and soil temperature spatial distributions. For snow depth, the latitudinal gradient is well respected. The lower soil temperature along a southwest-northeast transect is also well simulated.

The seasonal cycles of daily snow depths and monthly soil temperatures (Fig. 8) clearly show the biases of the CTL simulation and the improvements due to the new snow and soil representations. The seasonal cycles and the total skill scores are computed using the measurements and simulations for all stations over the entire observed periods. ISBA globally underestimates the snow depth from December through February with no clear difference between CTL and NEW (or NEW-SOC). However, springtime snowmelt is drastically improved by the new snow scheme which induces a better simulated seasonality. This fact is confirmed by some other quantitative comparisons. The average number of days per year with observed snow on the ground for all in situ stations is 150.7 days. CTL simulates 158.7 days against 151.5 days for NEW. On average, the last day of the snow season is day number 281.6 when starting on 1 July. CTL goes beyond this date by more than 9 days while for NEW it is only 2 days (day number 283). Theses results are consistent with the model evaluation at the Col de Porte field site (Sect. 4). As could be expected also, the new physical soil properties (NEW-SOC) play a minimal role in the snow depth simulation. The seasonal cycle of the soil temperature profile confirms that the new snow scheme induces a warmer soil in

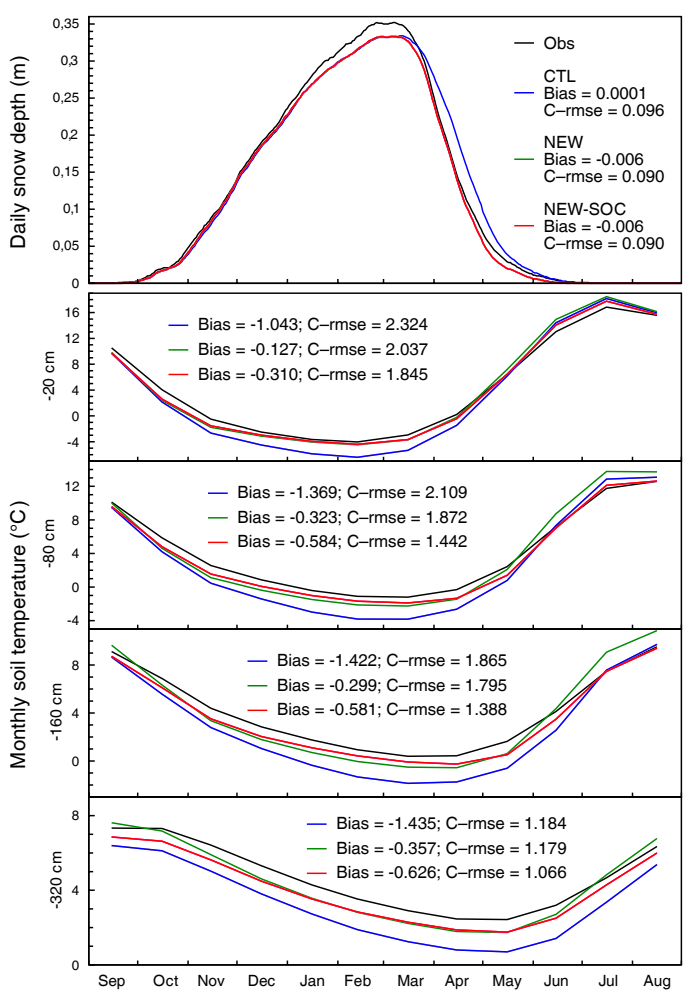

Figure 8. Mean annual cycles of observed and simulated daily snow depth and monthly soil temperature profiles. The mean cycles are computed by averaging all simulated or observed mean annual cycles at each station. However, total skill scores (bias and c-rmse) found in each panel are computed by merging together all simulated or observed time series of all stations over the entire observed periods.

winter compared to CTL, and it strongly reduces the cold bias of CTL. The effect of soil organic carbon is especially observable during spring and summer. NEW exhibits a warm bias for each soil horizon while NEW-SOC, with more insulating soils, reduces this weakness.

These improvements in snow depth and soil temperature are confirmed by the spatial distributions of their seasonal skill scores (bias and c-rmse). Figure 9 shows the spatial distributions of snow depth seasonal skill scores (bias and crmse) during winter and spring. No clear differences among these simulations appear in winter, while the bias and c-rmse of many stations are improved in spring by the new snow scheme. The springtime snow depth is simulated in an acceptable manner by NEW, while CTL exhibits a significant overestimation. This fact is confirmed by total scores given in each of the panels. In winter, regardless of the experiments, ISBA underestimates snow depth measurements at many stations, especially in the northern and western parts of the domain (Fig. 9).

The spatial distribution of soil temperature seasonal skill scores simulated at 20 and $160 \mathrm{~cm}$ depth during winter is 

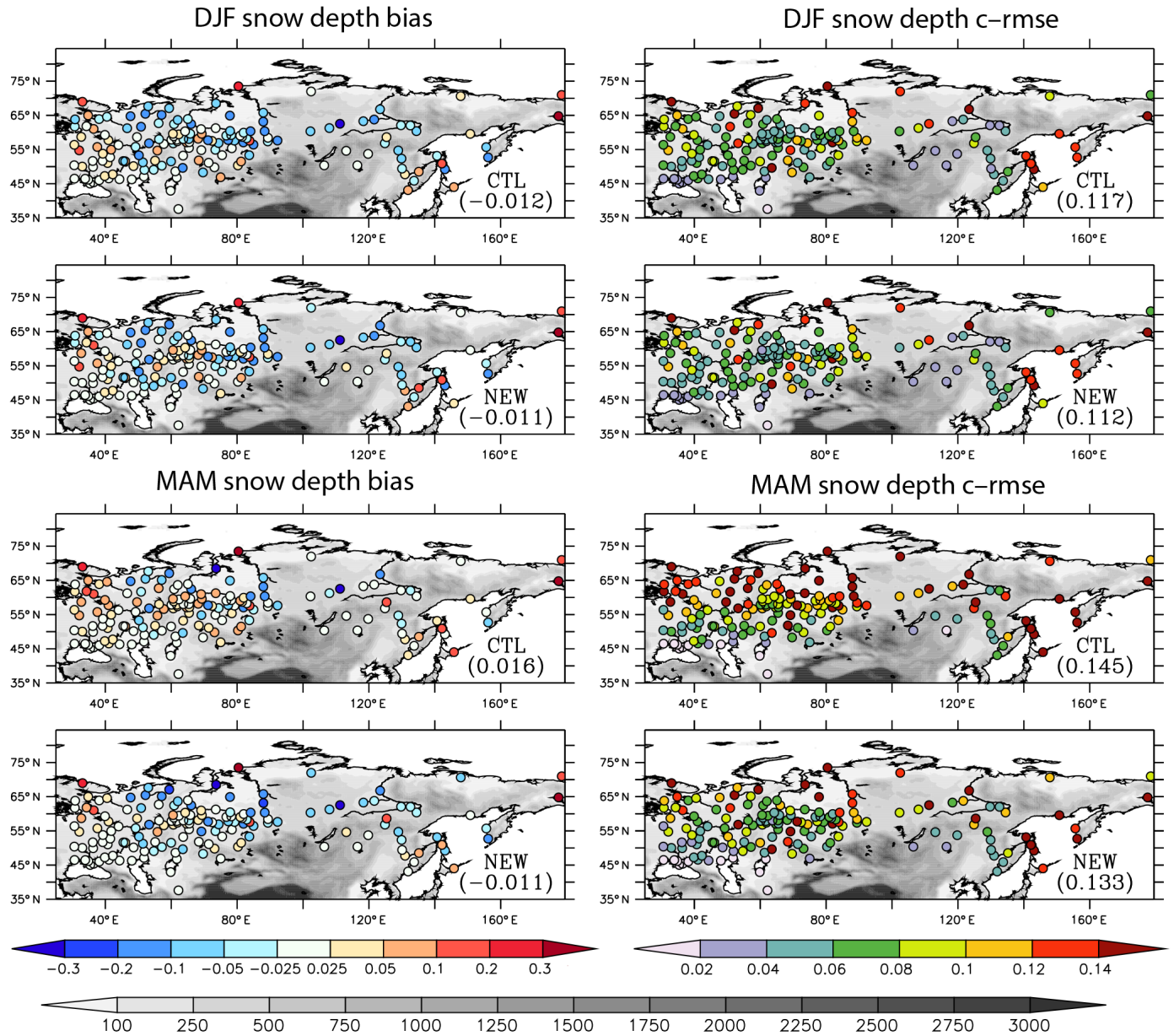

Figure 9. Daily snow depth skill scores (bias and c-rmse) simulated by the CTL and the NEW experiments during winter (DJF) and spring (MAM) over northern Eurasia and expressed in meters. Total scores given in parentheses are computed by merging together all simulated or observed daily time series of all stations for each season.

given in Fig. 10. Regardless of the region, the generalized cold bias found over all stations with CTL is drastically reduced with the new snow scheme and the interannual variability (c-rmse) is largely improved. In summer (Fig. 11), as was already shown in Fig. 8, NEW-SOC is in better agreement with observations compared to NEW regardless of the soil horizon (lower c-rmse) even if a slight cold bias appears at the subsurface as shown by the negative total bias found at $320 \mathrm{~cm}$ depth. The NEW experiment overestimates the temperature profile measurements at many stations near the surface, but less so at a $320 \mathrm{~cm}$ depth. Therefore, it seems that the subsurface cooling in the NEW-SOC experiment is too intensive, but in fact at $320 \mathrm{~cm}$ depth, the simulated soil temperature in the western part of the domain remains quasiunchanged between NEW-SOC and NEW. The best total scores found in Figs. 8 and 11 without soil organic carbon by the NEW experiment are in fact due to error compensation between the cold and warm biases simulated in the western and eastern part of the domain, respectively.
The effect of soil organic carbon content on soil temperature profile is also especially observable in terms of the simulated permafrost characteristics. The observed and simulated locations of permafrost boundaries are compared in Fig. 12. Regardless of the experiment, ISBA generally simulates acceptable boundaries even if the permafrost limit extends slightly too far south in the western part of the domain. This figure also shows the spatial distribution of active layer thicknesses simulated by the NEW and the NEW-SOC experiments. The active layer thickness in the model is computed as the maximum depth reached each year by the $0^{\circ} \mathrm{C}$ isotherm in the soil approximated via a linear interpolation between the last positive temperature node going down from the surface and the first negative temperature node. As expected from the lower summer soil temperatures with NEWSOC (Figs. 9 and 11), the active layer is shallower. However, this comparison with the limits of different permafrost types does not allow it to be determined which simulation leads to the most accurate active layer thicknesses. The compar- 

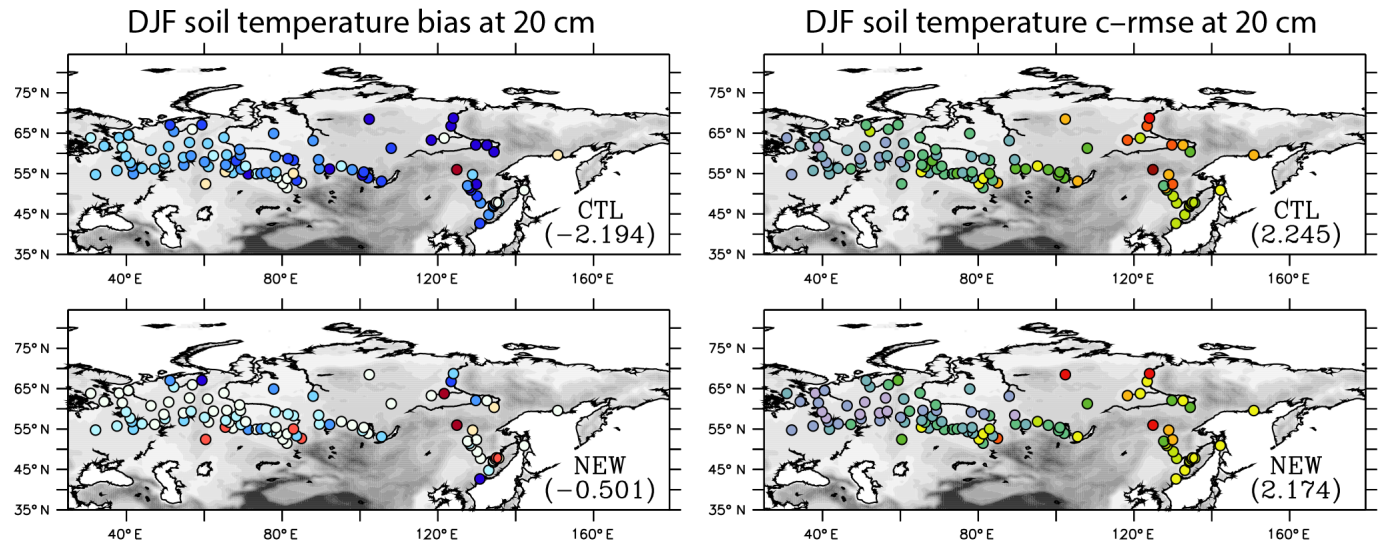

DJF soil temperature bias at $160 \mathrm{~cm}$

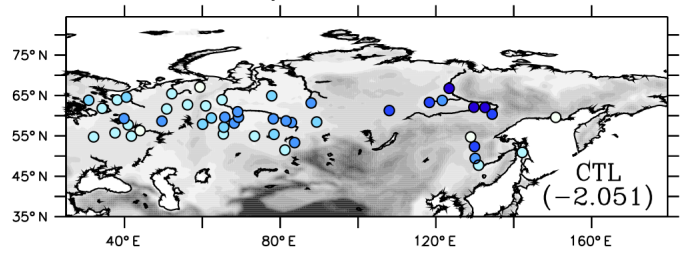

DJF soil temperature c-rmse at $160 \mathrm{~cm}$
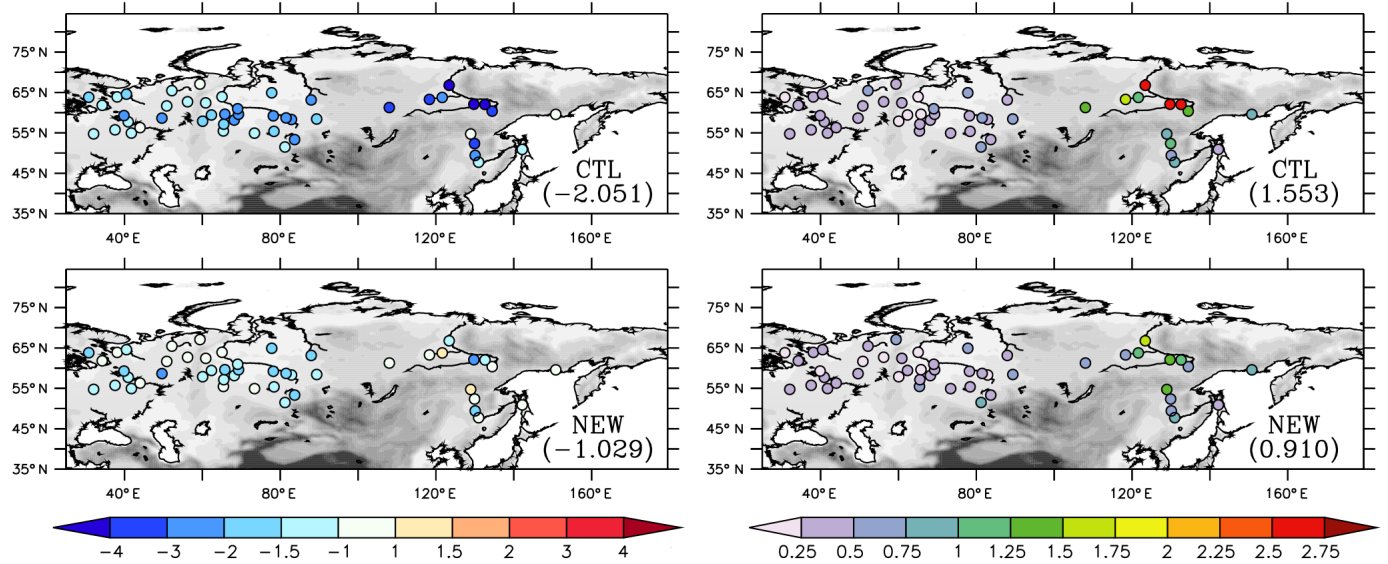

Figure 10. Monthly soil temperature skill scores at 20 and $160 \mathrm{~cm}$ depths simulated by the CTL and the NEW experiments during winter and expressed in degrees Celsius. Total scores (bias and c-rmse) are given for each panel.

ison with the CALM data given in Fig. 12 seems to show that NEW-SOC simulates a more accurate spatial distribution of the active layer thickness. This result is confirmed by Fig. 13 that shows the estimated and simulated active layer thicknesses over the Yakutia region. Estimations from Beer et al. (2013) present a strong latitudinal gradient with an increase in active layer thickness from the north to the south. Both experiments exhibit such profiles. However, the active layer thickness simulated by NEW-SOC is in better agreement with these estimations than those by NEW. The latitudinal zonal average confirms this result.

\section{Discussion and conclusion}

In this study, the impact of improved representation of snowpack and soil properties in the ISBA LSM to simulate snow characteristics and soil temperature profiles over cold regions was analyzed. ISBA's representations of snow layering, albedo, and compaction were updated by incorporating some parameterizations of the detailed Crocus snowpack model. In addition, a simple parameterization of the soil organic car- bon effect on hydraulic and thermal soil properties was introduced based on previous work (Boelter, 1969; Letts et al., 2000; Lawrence and Slater, 2008). The model is evaluated first over the Col de Porte field site in the French Alps (Morin et al., 2012) in order to isolate the changes in the snowpack parameterization, and second over the northern Eurasian region to analyze the model's ability to simulate snow depth, soil temperature profile, and permafrost characteristics.

Changes in the snowpack parameterizations induce noticeable improvements in the simulated snow depth, SWE, surface albedo, and soil temperature at the Col de Porte (field) site. The new snow layering algorithm with 12 layers permits a refinement of the vertical distribution of density and temperature in the snowpack, leading to slight improvements in simulated snow depth, SWE, and soil temperature during winter. The densification of the snowpack with the new compaction scheme, which increases the density contrast between the top and the bottom snow layers, has a significant positive impact on snow depth and winter soil temperature. Finally, the new spectral albedo scheme clearly improves the simulation of the springtime surface albedo that allows a bet- 

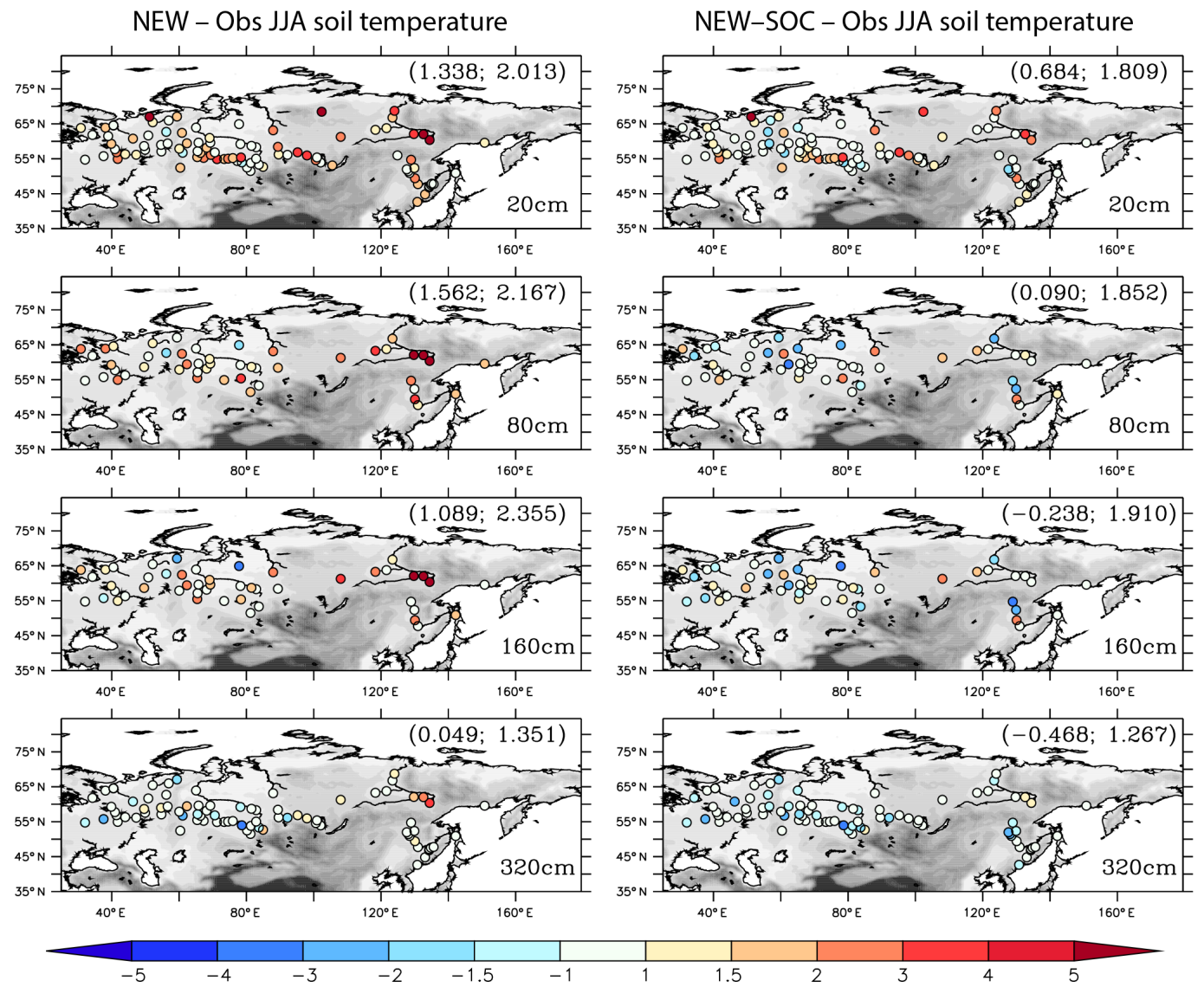

Figure 11. Monthly soil temperature profile bias simulated by the NEW (left panels) and the NEW-SOC (right panels) experiments during summer and expressed in degrees Celsius. Total skill scores (bias; c-rmse) are given in the top panel for each soil horizon.

ter simulation of the snowpack characteristics and soil temperature during melting at the end of the snow season.

It must be noted that the large improvement in snow albedo in spring is mainly due to the use of snow age in the diagnostics of the optical diameter of snow (Eq. 18). Without this parameterization, the surface albedo is strongly overestimated in winter and, to a lesser extent in spring at the $\mathrm{Col}$ de Porte field site, with a larger bias and c-rmse for all variables compared to the new version of ISBA (not shown). The optical diameter of snow strongly controls the near-infrared albedo, while impurities mostly affect the albedo in the visible spectrum (Wiscombe and Warren, 1980). This increase of snow optical diameter with time is necessary to represent the decrease in spectrally integrated albedo with age well. However, the increase of snow optical diameter is not only a function of snow density as parameterized by Anderson (1976) in Eq. (10), but it is also due to snow metamorphism, which is macroscopically driven by snow temperature and snow thermal gradients. Several complex parameterizations exist to explicitly represent the evolution of snow optical diameter according to these processes (e.g., Carmagnola et al., 2014). Nevertheless, for the sake of simplicity, we just use a snow age dependency in the diagnostic of snow optical diameter with a limitation at 15 days (Eq. 18). This simple diagnostic allows the model to reasonably match the explicit computation of the optical diameter of snow simulated in the Crocus model (not shown). The good results of the ISBA model at the Col de Porte field site reinforce this choice.

The positive impacts of the new ISBA snow scheme are confirmed when tested over the northern Eurasian region with an important number of open field in situ snow depth and soil temperature stations. Winter snow depths are slightly better simulated with the new version and the winter soil temperature cold bias obtained with the old version of ISBA is clearly reduced. This fact confirms that the physics used in snow schemes is of primary importance for adequately simulating the snow-insulating effect that prevents soil from getting too cold in winter (Slater et al., 2001; Luo et al., 2003; Gouttevin et al., 2012; Paquin and Sushama, 2015). Another important impact of changes in the ISBA snow scheme over the northern Eurasian region is seen in spring when the snowmelt is well reproduced. As shown over the Col de Porte (field) site, this is mainly due to the new parameterization of spectral snow albedo. 


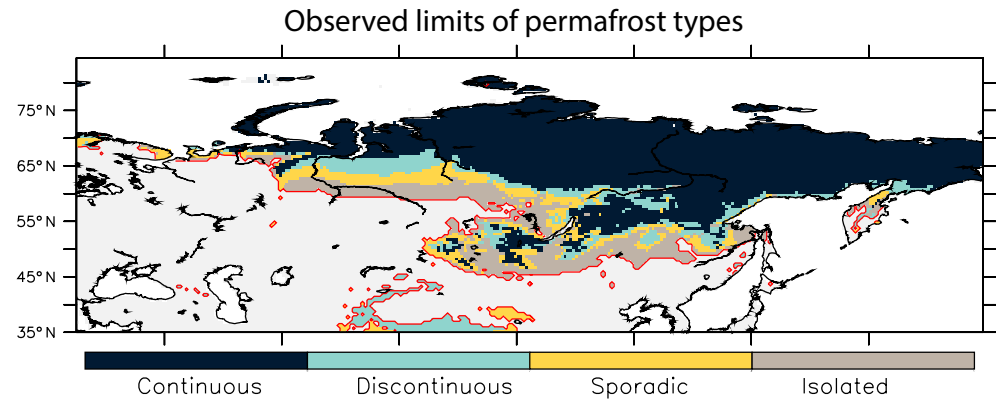

Simulated vs. observed active layer thickness $(\mathrm{m})$
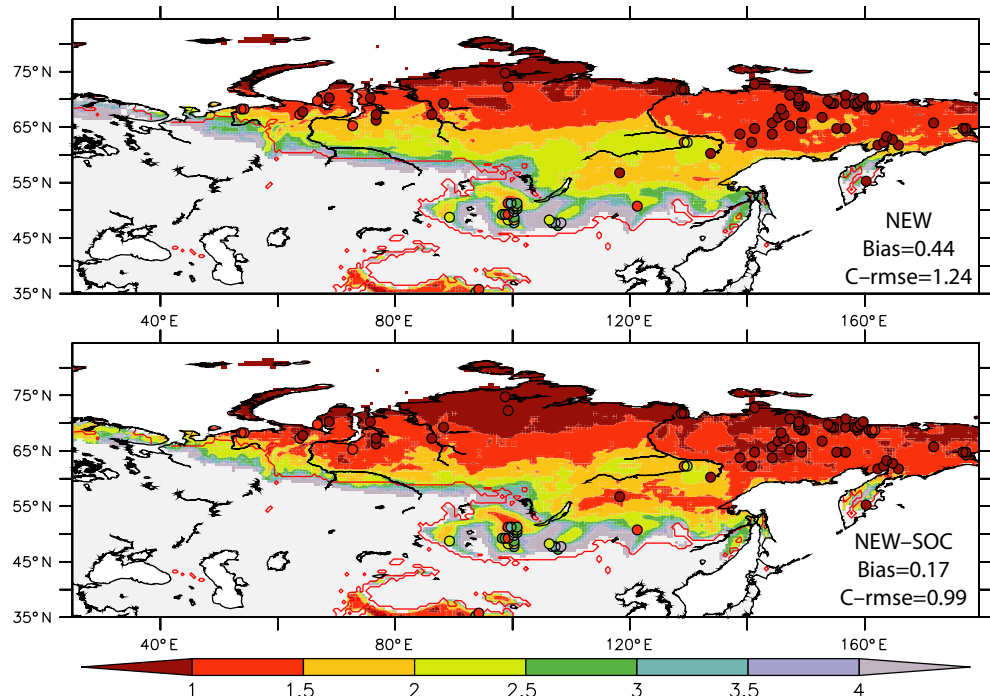

Figure 12. Distribution of permafrost characteristics. The NSIDC estimated limits of continuous, discontinuous, sporadic, and isolated permafrost regions are shown in the top panel. In each panel the red lines correspond to the observed boundary of the entire permafrost region. In the middle and the bottom panels, the mean active layer thicknesses simulated over the 1990-2013 period by the NEW and the NEW-SOC experiments are shown and compared to observations from the CALM network (circles). Total skill scores are given for each experiment.

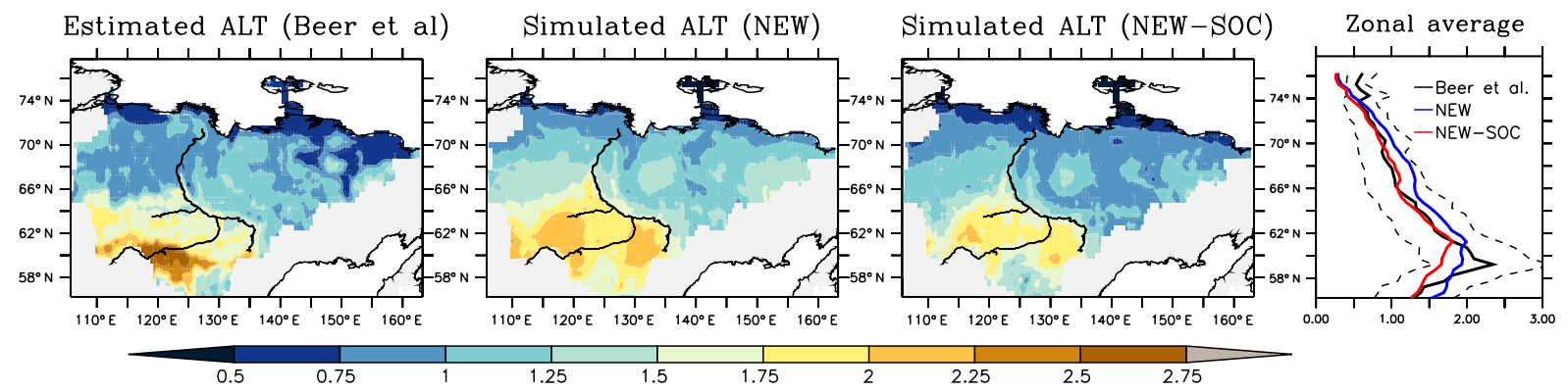

Figure 13. Estimated and simulated active layer thicknesses over the Yakutia region. Estimations before the 1990s are given by Beer et al. (2013), while the NEW and the NEW-SOC experiments are averaged over the 1979-1990 period. The estimated and simulated latitudinal zonal averages are shown in the last panel where Beer et al. (2013) estimations are in black, NEW in blue, and NEW-SOC in red. Dashed lines correspond to uncertainties in active layer thicknesses estimations computed using standard deviations provided by the data set.

Nevertheless, regardless of the model version used, simulated winter snow depths are generally underestimated compared to in situ observations. The cause of this underestimation is not trivial. The first source of uncertainty can be at- tributable to the GPCC precipitation measurements that do not account for wind undercatch, leading to a possible underestimation of solid precipitation during winter (Adam and Lettenmaier, 2003; Brun et al., 2013). Besides uncertainties 
related to the atmospheric forcing, the snow depth underestimation can be due to the inexplicit representation of snow metamorphism. Indeed, in similar experimental conditions over the northern Eurasian region, the winter snow depth simulated by the detailed Crocus snowpack model did not exhibit the same problem (Brun et al., 2013) and the main remaining difference between Crocus and ISBA is now restricted almost entirely to the explicit simulation of snow metamorphism. In Crocus, the viscosity of layers, composed of faceted crystals and depth hoar snow types, is increased (Vionnet et al., 2012), which leads to a reduction of the overall compaction rate of snowpack undergoing temperature conditions conducive to such snow types, and this is consistent with the situation described above.

Taking into account soil organic carbon in soil physical properties logically plays a minimal role in the simulated snowpack behavior. However, this process has drastic impacts on the summer soil temperature profile because it allows the soil to remain cool during spring and summer as shown in previous studies (Bonan and Shugart, 1989; Lawrence and Slater, 2008; Dankers et al., 2011). Consequently, the spatial distribution of the permafrost active layer thickness simulated by the new version of ISBA is in better agreement with estimations from Beer et al. (2013) over the Yakutia region. This result is in agreement with Paquin and Sushama (2015) who showed that the hydraulic and thermal properties of soil organic carbon partly control the thickness of the active layer during summer. However, spatial observations of permafrost characteristics on the global scale are still very scarce, and if available, they are static and do not allow the study of long-term trends and interannual variability.
This model validation should ideally be extended over all cold regions (e.g., North America, Greenland) but considering that northern Eurasia is representative of such regions, some important conclusions are confirmed by this study.

- An adequate simulation of snow layering and snow compaction/densification is important in order to represent winter snowpack characteristics and the soil temperature profile well.

- Snow albedo strongly controls the simulation of the springtime snow characteristics and the melting timing.

- Accounting for soil organic carbon in terms of the soil physical properties drastically impacts the simulation of the summer soil temperature profile and hence also the permafrost active layer thickness and its spatial distribution.

Finally, these conclusions underscore the fact that the representation of snowpack characteristics and soil thermal processes are of primary importance for studying permafrost vulnerability under climate change conditions, especially if the continental carbon cycle is considered due to the strong interaction between soil thermal processes and soil organic carbon decomposition with release of greenhouse gases.

\section{Data availability}

All data are available on the mentioned web site. 


\section{Appendix A: Snow thermal conductivity}

The snow thermal conductivity is computed as a function of snow density following Yen (1981). It also accounts for vapor transfer in the snow using a simple parameterization from Sun et al. (1999). This process is especially important at low snow densities and at high altitude. Therefore, the snow thermal conductivity, $\lambda_{\mathrm{sn}}\left(\mathrm{W} \mathrm{m}^{-1} \mathrm{~K}^{-1}\right)$, in each layer is given by

$\lambda_{\mathrm{sn}}(i)=\lambda_{\mathrm{ice}}\left(\frac{\rho_{\mathrm{sn}}(i)}{\rho_{\mathrm{w}}}\right)^{1.88}+\frac{P_{0}}{P_{\mathrm{a}}} \times \max \left(0, k_{1}-\frac{k_{2}}{T_{\mathrm{sn}}(i)-k_{3}}\right)$,

where $\lambda_{\text {ice }}\left(\mathrm{W} \mathrm{m}^{-1} \mathrm{~K}^{-1}\right)$ is the thermal conductivity of ice equal to $2.2 \mathrm{~W} \mathrm{~m}^{-1} \mathrm{~K}^{-1}, \rho_{\mathrm{w}}\left(\mathrm{kg} \mathrm{m}^{-3}\right)$ the water density, $P_{\mathrm{a}}$ $(\mathrm{Pa})$ the air pressure, $P_{0}(\mathrm{~Pa})$ a reference pressure equal to $1000 \mathrm{hPa}$, and the coefficients $k_{1}=-0.06023 \mathrm{~W} \mathrm{~m}^{-1} \mathrm{~K}^{-1}$, $k_{2}=2.5425 \mathrm{~W} \mathrm{~m}^{-1}$, and $k_{3}=289.99 \mathrm{~K}$.

\section{Appendix B: Wind-induced densification of near-surface snow layers}

Following Brun et al. (1997), the compaction rate, $\tau_{\mathrm{w}}$, of wind-induced densification of near-surface snow layers is computed using several steps. First, a mobility index, $\Gamma_{\text {mob }}$, that describes the potential for snow erosion for each snow layer is computed as a function of snow density:

$\Gamma_{\mathrm{mob}}(i)=a_{\mathrm{mob}}\left[1.0-\max \left(0, \frac{\rho_{\mathrm{s}}(i)-\rho_{\mathrm{sn} \min }}{\rho_{\mathrm{mob}}}\right)\right]$,

where $\rho_{\mathrm{sn} \min }=50 \mathrm{~kg} \mathrm{~m}^{-3}$ is the minimum density of snow, $\rho_{\text {mob }}$ a reference density of $295 \mathrm{~kg} \cdot \mathrm{m}^{-3}$, and the dimensionless constant $a_{\mathrm{mob}}=1.25$. Secondly, a wind-driven compaction index is computed, $\Gamma_{\mathrm{w}}$, combining the mobility index and the near-surface atmospheric wind speed:

$\Gamma_{\mathrm{w}}(i)=1-a_{\Gamma} \exp \left(-b_{\Gamma} \kappa_{v} V_{\mathrm{a}}\right)+\Gamma_{\mathrm{mob}}(i)$,

where $\kappa_{v}=1.25$ is a dimensionless coefficient for gust diagnosis from average wind speed, and the constants $a_{\Gamma}=2.868$ and $b_{\Gamma}=0.085 \mathrm{~s} \mathrm{~m}^{-1}$. A positive value of $\Gamma_{\mathrm{w}}$ indicates that wind-driven compaction can occur. Compaction rate from the surface is then propagated to the layers beneath, following an exponential decrease, until it meets a snow layer with a negative wind-driven compaction index. For each layer, this compaction rate is computed as follows:

$$
\begin{aligned}
\tau_{\mathrm{w}}(i) & =\frac{2 \kappa_{v} \pi_{\tau}}{f_{\tau}(i)} \text { with } f_{\tau}(i)=\max \left(0, \Gamma_{\mathrm{w}}(i)\right) \\
& \times \exp \left(a_{\tau} \sum_{j=1}^{i}\left(\Delta z(j)\left(b_{\tau}-\Gamma_{\mathrm{w}}(j)\right)\right)\right),
\end{aligned}
$$

where $\pi_{\tau}$ (s) is a time constant of 1 day, and the constants $a_{\tau}=10$ and $b_{\tau}=3.25$.

\section{Appendix C: Grid-cell snow fraction}

At regional and/or global scale, the snow fraction, $p_{\mathrm{sn}}$, for each patch of the ISBA land surface model is computed as the sum of the bare ground snow-covered fraction, $p_{\text {sng }}$, and the fraction of vegetation covered by snow, $p_{\mathrm{snv}}$, weighted by the vegetation fraction of the patches covered by vegetation, $f_{\text {veg. }}$. The snow fraction is thus computed as follows:

$$
\begin{aligned}
p_{\mathrm{sn}}=\left(1-f_{\mathrm{veg}}\right) p_{\mathrm{sng}}+f_{\mathrm{veg}} p_{\mathrm{snv}} \\
\text { with } \mid \begin{array}{l}
p_{\mathrm{sng}}=\min \left(1, h_{\mathrm{sn}} / h_{\mathrm{sng}}\right) \\
p_{\mathrm{snv}}=h_{\mathrm{sn}} /\left(h_{\mathrm{sn}}+w_{\mathrm{snv}} z_{0 \mathrm{veg}}\right)
\end{array}
\end{aligned},
$$

where $h_{\mathrm{sn}}(\mathrm{m})$ is the total snow depth, $h_{\text {sng }}(\mathrm{m})$ a ground snow depth threshold set to $0.01 \mathrm{~m}, z_{0 \mathrm{veg}}(\mathrm{m})$ the vegetation roughness length, and $w_{\text {snv }}$ a coefficient set to 2 . $f_{\text {veg }}$ is specified for each vegetation patch. It is equal to 0.0 for bare soil, 0.95 for grassland/tundra as well as for temperate and boreal forest, and varies exponentially according to the leaf area index (LAI) for crop types. $z_{0 \mathrm{veg}}$ varies for each vegetation type and is computed from typical vegetation height, $h_{\mathrm{veg}}$, as follows:

$z_{0 \mathrm{veg}}=\max \left(0.001,0.13 \times h_{\mathrm{veg}}\right)$.

For woody vegetation, $h_{\text {veg }}$ is assumed constant over time. It ranges from $30 \mathrm{~m}$ for tropical forests and $20 \mathrm{~m}$ for coniferous boreal forests to 15,10 , or $5 \mathrm{~m}$ for temperate forests and $2 \mathrm{~m}$ for bushes. For herbaceous plants, $h_{\mathrm{veg}}=\mathrm{LAI} / 6$, with LAI the leaf area index given by the ECOCLIMAP database. It ranges approximately from 0.01 to $0.8 \mathrm{~m}$ for grassland/tundra. Finally, the height of crop types is related to an exponential function of LAI and has a height of $1 \mathrm{~m}$ before maturity defined as a LAI of $3.5 \mathrm{~m}^{2} \mathrm{~m}^{-2}$. More details on these physiographic parameters can be found in Masson et al. (2003). 
Acknowledgements. This work is supported by the APT project from the BNP-Paribas foundation, the program CLASSIQUE of the French Agence Nationale pour la Recherche, the Centre National de Recherches Météorologiques (CNRM) of Méteo France, and the Centre National de la Recherche Scientifique (CNRS) of the French research ministry. The authors would like to thank in particular Vincent Vionnet, Matthieu Lafaysse, Yves Lejeune, and Jean-Michel Panel (CNRM-GAME/Centre d'Etudes de la Neige) for useful comments on snowpack modeling and their contribution to data acquisition at Col de Porte since 1993. Thanks are also due to anonymous reviewers.

Edited by: G. Chambon

\section{References}

Adam, J. C. and Lettenmaier, D. P.: Adjustment of global gridded precipitation for systematic bias, J. Geophys. Res., 108, 4257, doi:10.1029/2002JD002499, 2003.

Anderson, E. A.: A point energy and mass balance model of a snow cover, Technical Report NWS 19, National Oceanic and Atmospheric Administration (NOAA), Silver Spring, MD, USA, 150 pp., 1976.

Armstrong, R.: Historical Soviet daily snow depth version 2 (HSDSD), National Snow and Ice Data Center, Boulder, CO, CDROM, http://nsidc.org/data/docs/noaa/g01092_hsdsd/index.html (last access: April 2016), 2001.

Armstrong, R. L. and Brun, E.: Snow and Climate: Physical Processes, Surface Energy Exchange and Modeling, Cambridge University Press, 222 pp., 2008.

Bartelt, P. and Lehning, M.: A physical SNOWPACK model for the Swiss avalanche warning: Part I: numerical model, Cold Reg. Sci. Technol., 35, 123-145, 2002.

Beer, C., Fedorov, A. N., and Torgovkin, Y.: Permafrost temperature and active-layer thickness of Yakutia with 0.5-degree spatial resolution for model evaluation, Earth Syst. Sci. Data, 5, 305-310, doi:10.5194/essd-5-305-2013, 2013.

Beringer, J., Lynch, A. H., Chapin III, F. S., Mack, M., and Bonan, G. B.: The Representation of Arctic Soils in the Land Surface Model: The Importance of Mosses, J. Climate, 14, 3324-3335, doi:10.1175/1520-0442(2001)014<3324:TROASI>2.0.CO;2, 2001.

Berrisford, P., Kållberg, P., Kobayashi, S., Dee, D., Uppala, S., Simmons, A. J., Poli, P., and Sato, H.: Atmospheric conservation properties in ERA-Interim, Q. J. Roy. Meteorol. Soc., 137, 13811399, doi:10.1002/qj.864, 2011.

Best, M. J., Pryor, M., Clark, D. B., Rooney, G. G., Essery, R. L. H., Ménard, C. B., Edwards, J. M., Hendry, M. A., Porson, A., Gedney, N., Mercado, L. M., Sitch, S., Blyth, E., Boucher, O., Cox, P. M., Grimmond, C. S. B., and Harding, R. J.: The Joint UK Land Environment Simulator (JULES), Model description Part 1: Energy and water fluxes, Geosci. Model Dev., 4, 677-699, doi:10.5194/gmd-4-677-2011, 2011.

Boelter, D. H.: Physical Properties of Peats as Related to Degree of Decomposition, Soil Sci. Soc. Am. J., 33, 606-609, doi:10.2136/sssaj1969.03615995003300040033x, 1969.
Bohren, C. F. and Barkstrom, B. R.: Theory of the optical properties of snow, J. Geophys. Res., 79, 4527-4535, doi:10.1029/JC079i030p04527, 1974.

Bonan, G. B. and Shugart, H. H.: Environmental-factors and ecological processes in boreal forests, Annu. Rev. Ecol. Syst., 20, 1-28, 1989.

Boone, A. and Etchevers, P.: An intercomparison of three snow schemes of varying complexity coupled to the same land-surface model: Local scale evaluation at an Alpine site, J. Hydrometeorol., 2, 374-394, 2001.

Boone, A., Masson, V., Meyers, T., and Noilhan, J.: The influence of the inclusion of soil freezing on simulations by a soilvegetation-atmosphere transfer scheme, J. Appl. Meteorol., 39, 1544-1569, 2000.

Braud, I., Varado, N., and Olioso, A.: Comparison of root water uptake modules using either the surface energy balance or potential transpiration, J. Hydrol., 301, 267-286, 2005.

Brooks, R. H. and Corey, A. T.: Properties of porous media affecting fluid flow, J. Irrig. Drain. Div., 92, 61-90, 1966.

Brown, J., Hinkel, K. M., and Nelson, F. E.: The Circumpolar Active Layer Monitoring (CALM) program: historical perspectives and initial results, Polar Geogr., 24, 165-258, 2000.

Brown, J., Ferrians, O., Heginbottom, J. A., and Melnikov, E.: Circum-Arctic Map of Permafrost and Ground-Ice Conditions, Version 2, National Snow and Ice Data Center (NSIDC), Boulder, Colorado, USA, 2002.

Brown, R., Bartlett, P., MacKay, M., and Verseghy, D.: Evaluation of snow cover in CLASS for SnowMIP, Atmos.-Ocean, 44, $223-$ 238, doi:10.3137/ao.440302, 2006.

Brun, E., Martin, E., Simon, V., Gendre, C., and Coléou, C.: An energy and mass model of snow cover suitable for operational avalanche forecasting, J. Glaciol., 35, 333-342, 1989.

Brun, E., David, P., Sudul, M., and Brunot, G.: A numerical model to simulate snow-cover stratigraphy for operational avalanche forecasting, J. Glaciol., 38, 13-22, 1992.

Brun, E., Martin, E., and Spiridonov, V.: Coupling a multi-layered snow model with a GCM, Ann. Glaciol., 25, 66-72, 1997.

Brun, E., Vionnet, V., Boone, A., Decharme, B., Peings, Y., Valette, R., Karbou, F., and Morin, S.: Simulation of Northern Eurasian Local Snow Depth, Mass, and Density Using a Detailed Snowpack Model and Meteorological Reanalyses, J. Hydrometeorol., 14, 203-219, doi:10.1175/JHM-D-12-012.1, 2013.

Campbell, G. S.: A simple method for determining unsaturated conductivity from moisture retention data, Soil Science, 117, 311314, 1974.

Canadell, J., Jackson, R. B., Ehleringer, J. R., Mooney, H. A., Sala, O. E., and Schulze, E.-D.: Maximum rooting depth of vegetation types at the global scale, Oecologia, 108, 583-595, 1996.

Canal, N., Calvet, J.-C., Decharme, B., Carrer, D., Lafont, S., and Pigeon, G.: Evaluation of root water uptake in the ISBA-A-gs land surface model using agricultural yield statistics over France, Hydrol. Earth Syst. Sci., 18, 4979-4999, doi:10.5194/hess-184979-2014, 2014.

Carmagnola, C. M., Morin, S., Lafaysse, M., Domine, F., Lesaffre, B., Lejeune, Y., Picard, G., and Arnaud, L.: Implementation and evaluation of prognostic representations of the optical diameter of snow in the SURFEX/ISBA-Crocus detailed snowpack model, The Cryosphere, 8, 417-437, doi:10.5194/tc-8-417-2014, 2014. 
Dankers, R., Burke, E. J., and Price, J.: Simulation of permafrost and seasonal thaw depth in the JULES land surface scheme, The Cryosphere, 5, 773-790, doi:10.5194/tc-5-773-2011, 2011.

Decharme, B. and Douville, H.: Uncertainties in the GSWP2 precipitation forcing and their impacts on regional and global hydrological simulations, Clim. Dynam., 27, 695-713, doi:10.1007/s00382-006-0160-6, 2006a.

Decharme, B. and Douville, H.: Introduction of a sub-grid hydrology in the ISBA land surface model, Clim. Dynam., 26, 65-78, 2006b.

Decharme, B. and Douville, H.: Global validation of the ISBA SubGrid Hydrology, Clim. Dynam., 29, 21-37, doi:10.1007/s00382006-0216-7, 2007.

Decharme, B., Boone, A., Delire, C., and Noilhan, J.: Local evaluation of the Interaction between Soil Biosphere Atmosphere soil multilayer diffusion scheme using four pedotransfer functions, J. Geophys. Res., 116, D20126, doi:10.1029/2011JD016002, 2011.

Decharme, B., Martin, E., and Faroux, S.: Reconciling soil thermal and hydrological lower boundary conditions in land surface models, J. Geophys. Res.-Atmos., 118, 7819-7834, doi:10.1002/jgrd.50631, 2013.

Dee, D. P., Uppala, S. M., Simmons, A. J., Berrisford, P., Poli, P., Kobayashi, S., Andrae, U., Balmaseda, M. A., Balsamo, G., Bauer, P., Bechtold, P., Beljaars, A. C. M., van de Berg, L., Bidlot, J., Bormann, N., Delsol, C., Dragani, R., Fuentes, M., Geer, A. J., Haimberger, L., Healy, S. B., Hersbach, H., Hólm, E. V., Isaksen, L., Kållberg, P., Köhler, M., Matricardi, M., McNally, A. P., Monge-Sanz, B. M., Morcrette, J.-J., Park, B.-K., Peubey, C., de Rosnay, P., Tavolato, C., Thépaut, J.-N., and Vitart, F.: The ERA-Interim reanalysis: configuration and performance of the data assimilation system, Q. J. Roy. Meteorol. Soc., 137, 553597, doi:10.1002/qj.828, 2011.

Douville, H., Royer, J., and Mahfouf, J.: A new snow parameterization for the Meteo-France climate model, Clim. Dynam., 12, 21-35, 1995.

Dutra, E., Balsamo, G., Viterbo, P., Miranda, P., Beljaars, A., Schär, C., and Elder, K.: An improved snow scheme for the ECMWF land surface model: description and offline validation, J. Hydrometeorol., 11, 899-916, 2010.

FAO/IIASA/ISRIC/ISSCAS/JRC: Harmonized World Soil Database (version 1.2), FAO, Rome, Italy and IIASA, Laxenburg, Austria, 2012.

Farouki, O. T.: Thermal Properties of Soils, Series on Rock and Soil Mechanics, 11, Trans Tech Pub., Rockport, MA, USA, 136 pp., 1986.

Faroux, S., Kaptué Tchuenté, A. T., Roujean, J.-L., Masson, V., Martin, E., and Le Moigne, P.: ECOCLIMAP-II/Europe: a twofold database of ecosystems and surface parameters at $1-\mathrm{km}$ resolution based on satellite information for use in land surface, meteorological and climate models, Geosci. Model Dev., 6, $563-$ 582, doi:10.5194/gmd-6-563-2013, 2013.

Feddes, R. A., Hoff, H., Bruen, M., Dawson, T., de Rosnay, P., Dirmeyer, P., Jackson, R. B., Kabat, P., Kleidon, A., Lilly, A., and Pitman, A. J.: Modeling Root Water Uptake in Hydrological and Climate Models, B. Am. Meteorol. Soc., 82, 2797-2809, 2001.

Fuchs, M., Campbell, G. S., and Papendick, R. I.: An analysis of sensible and latent heat flow in a partially frozen unsaturated soil, Soil Sci. Soc. Am. J., 42, 379-385, 1978.
Gouttevin, I., Krinner, G., Ciais, P., Polcher, J., and Legout, C.: Multi-scale validation of a new soil freezing scheme for a landsurface model with physically-based hydrology, The Cryosphere, 6, 407-430, doi:10.5194/tc-6-407-2012, 2012.

Joetzjer, E., Delire, C., Douville, H., Ciais, P., Decharme, B., Carrer, D., Verbeeck, H., De Weirdt, M., and Bonal, D.: Improving the ISBACC land surface model simulation of water and carbon fluxes and stocks over the Amazon forest, Geosci. Model Dev., 8, 1709-1727, doi:10.5194/gmd-8-1709-2015, 2015.

Jordan, R.: A One-Dimensional Temperature Model for a Snow Cover: Technical Documentation for SNTHERM, Tech. rep. 89, Cold Regions Research and Engineering Lab., Hanover, NH, 149, 1991.

Kuipers Munneke, P., van den Broeke, M., Lenaerts, J., Flanner, M., Gardner, A., and van de Berg, W.: A new albedo parameterization for use in climate models over the Antarctic ice sheet, J. Geophys. Res., 116, D05114, doi:10.1029/2010JD015113, 2011.

Lafaysse, M., Morin, S., Coléou, C., Vernay, M., Serça, D., Besson, F., Willemet, J.-M., Giraud, G., and Durand, Y.: Towards a new chain of models for avalanche hazard forecasting in French mountain ranges, including low altitude mountains, Proceedings of the International Snow Science Workshop Grenoble, Chamonix Mont-Blanc, 7-11 October 2013, Grenoble, France, 162166, 2013.

Lawrence, D. M. and Slater, A.: Incorporating organic soil into a global climate model, Clim. Dynam., 30, 145-160, doi:10.1007/s00382-007-0278-1, 2008.

Lawrence, D. M., Slater, A. G., Romanovsky, V. E., and Nicolsky, D. J.: The sensitivity of a model projection of nearsurface permafrost degradation to soil column depth and inclusion of soil organic mater, J. Geophys. Res., 113, F02011, doi:10.1029/2007JF000883, 2008.

Letts, M. G., Roulet, N. T., Comer, N. T., Skarupa, M. R., and Verseghy, D. L.: Parametrization of peatland hydraulic properties for the Canadian Land Surface Scheme, Atmos. Ocean, 38, 141-160, 2000.

Loth, B. and Graf, H.-F.: Modeling the snow cover in climate studies: 1. Long-term integrations under different climatic conditions using a multilayered snow-cover model, J. Geophys. Res., 103, 11313-11327, doi:10.1029/97JD01411, 1998.

Loth, B., Graf, H.-F., and Oberhuber, J. M.: Snow cover model for global climate simulations, J. Geophys. Res., 98, 10451-10464, 1993.

Luo, L., Robock, A., Vinnikov, K., Schlosser, C., Slater, A., Boone, A., Etchevers, P., Habets, F., Noilhan, J., Braden, H., Cox, P., de Rosnay, P., Dickinson, R., Dai, Y., Duan, Q., Etchevers, P., Henderson-Sellers, A., Gedney, N., Gusev, Y., Habets, F., Kim, J., Kowalczyk, E., Mitchell, K., Nasonova, O., Noilhan, J., Pitman, A., Schaake, J., Shmakin, A., Smirnova, T., Wetzel, P., Xue, Y., Yang, Z. and Zeng, Q.: Effects of frozen soil on soil temperature, spring infiltration, and runoff: Results from the PILPS2(d) experiment at Valdai, Russia, J. Hydrometeorol., 4, 334-351, doi:10.1175/1525-7541(2003)4<334:EOFSOS>2.0.CO;2, 2003.

Lynch-Stieglitz, M.: The development and validation of a simple snow model for the GISS GCM, J. Climate, 7, 1842-1855, 1994.

Manabe, S.: Climate and ocean circulation 1. The atmospheric circulation and the hydrology of the earth's surface, Mon. Weather Rev., 97, 739-805, 1969 
Masson, V., Champeaux, J.-L., Chauvin, F., Meriguet, C., and Lacaze, R.: A Global Database of Land Surface Parameters at $1-\mathrm{km}$ Resolution in Meteorological and Climate Models, J. Climate, 16, 1261-1282, doi:10.1175/15200442(2003)16<1261:AGDOLS>2.0.CO;2, 2003.

Masson, V., Le Moigne, P., Martin, E., Faroux, S., Alias, A., Alkama, R., Belamari, S., Barbu, A., Boone, A., Bouyssel, F., Brousseau, P., Brun, E., Calvet, J.-C., Carrer, D., Decharme, B., Delire, C., Donier, S., Essaouini, K., Gibelin, A.-L., Giordani, H., Habets, F., Jidane, M., Kerdraon, G., Kourzeneva, E., Lafaysse, M., Lafont, S., Lebeaupin Brossier, C., Lemonsu, A., Mahfouf, J.-F., Marguinaud, P., Mokhtari, M., Morin, S., Pigeon, G., Salgado, R., Seity, Y., Taillefer, F., Tanguy, G., Tulet, P., Vincendon, B., Vionnet, V., and Voldoire, A.: The SURFEXv7.2 land and ocean surface platform for coupled or offline simulation of earth surface variables and fluxes, Geosci. Model Dev., 6, 929-960, doi:10.5194/gmd-6-929-2013, 2013.

Morin, S., Lejeune, Y., Lesaffre, B., Panel, J.-M., Poncet, D., David, P., and Sudul, M.: An 18-yr long (1993-2011) snow and meteorological dataset from a mid-altitude mountain site (Col de Porte, France, $1325 \mathrm{~m}$ alt.) for driving and evaluating snowpack models, Earth Syst. Sci. Data, 4, 13-21, doi:10.5194/essd-4-13-2012, 2012.

Nicolsky, D. J., Romanovsky, V. E., Alexeev, V. A., and Lawrence, D. M.: Improved modeling of permafrost dynamics in Alaska with CLM3, Geophys. Res. Lett., 34, L08501, doi:10.1029/2007GL029525, 2007.

Niu, G. Y. and Yang, Z. L.: Effects of frozen soil on snowmelt runoff and soil water storage at a continental scale, J. Hydrometeorol, 7, 937-952, 2006.

Noilhan, J. and Lacarrère, P.: GCM gridscale evaporation from mesoscale modeling, J. Climate, 8, 206-223, 1995.

Oleson, K. W., Lawrence, D. M., Bonan, G. B., Flanner, M. G., Kluzek, E., Lawrence, P. J., Levis, S., Swenson, S. C., Thornton, P. E., Dai, A., Decker, M., Dickinson, R., Feddema, J., Heald, C. L., Hoffman, F., Lamarque, J.-F., Mahowald, N., Niu, G.Y., Qian, T., Randerson, J., Running, S., Sakaguchi, K., Slater, A., Stockli, R., Wang, A., Yang, Z.-L., Zeng, X., Zeng, X.: Technical Description of version 4.0 of the Community Land Model (CLM), NCAR Technical Note NCAR/TN-478+STR, NCAR, Boulder, Colorado, 1-257, doi:10.5065/D6FB50WZ, 2010.

Pahaut, E.: La métamorphose des cristaux de neige (Snow crystal metamorphosis), Monographies de la Météorologie Nationale, No. 96, Météo-France, Direction de la météorologie nationale, France, 58 pp., 1976.

Paquin J.-P. and Sushama, L.: On the Arctic near-surface permafrost and climate sensitivities to soil and snow model formulations in climate models, Clim. Dynam., 44, 203-228, doi:10.1007/s00382-014-2185-6, 2015.

Parrens, M., Calvet, J. C., de Rosnay, P., and Decharme, B.: Benchmarking of L-band soil microwave emission models, Remote Sens. Environ., 140, 407-419, doi:10.1016/j.rse.2013.09.017, 2014.

Peters-Lidard, C. D., Blackburn, E., Liang, X., and Wood, E. F.: The effect of soil thermal conductivity parameterization on surface energy fluxes and temperatures, J. Atmos. Sci., 55, 1209-1224, 1998.
Poutou, E., Krinner, G., Genthon, C., and de Noblet-Ducoudré, N.: Role of soil freezing in future boreal climate change, Clim. Dynam., 23, 621-639, doi:10.1007/s00382-004-0459-0, 2004.

Schleef, S., Löwe, H., and Schneebeli, M.: Influence of stress, temperature and crystal morphology on isothermal densification and specific surface area decrease of new snow, The Cryosphere, 8 , 1825-1838, doi:10.5194/tc-8-1825-2014, 2014.

Schneider, U., Becker, A., Finger, P., Meyer-Christoffer, A., Rudolf, B., and Ziese, M.: GPCC Full Data Reanalysis Version 6.0 at $0.5^{\circ}$ : Monthly Land-Surface Precipitation from Rain-Gauges built on GTS-based and Historic Data, doi:10.5676/DWD_GPCC/FD_M_V6_050, 2011.

Shrestha, M.,Wang, L., Koike, T., Xue, Y., and Hirabayashi, Y.: Improving the snow physics of WEB-DHM and its point evaluation at the SnowMIP sites, Hydrol. Earth Syst. Sci., 14, 2577-2594, doi:10.5194/hess-14-2577-2010, 2010.

Slater, A. G., Schlosser, C. A., Desborough, C. E., Pitman, A. J., Henderson-Sellers, A., Robock, A., Ya Vinnikov, K., Entin, J., Mitchell, K., Chen, F., Boone, A., Etchevers, P., Habets, F., Noilhan, J., Braden, H., Cox, P. M., de Rosnay, P., Dickinson, R. E., Yang, Z.-L., Dai, Y.-J., Zeng, Q., Duan, Q., Koren, V., Schaake, S., Gedney, N., Gusev, Y. M., Nasonova, O. N., Kim, J., Kowalczyk, E. A., Shmakin, A. B., Smirnova, T. G., Verseghy, D., Wetzel, P., and Xue, Y.: The Representation of Snow in Land Surface Schemes: Results from PILPS 2(d), J. Hydrometeorol., 2, 7-25, doi:10.1175/15257541(2001)002<0007:TROSIL>2.0.CO;2, 2001.

Sun, S., Jin, J., and Xue, Y.: A simple snow-atmosphere-soil transfer (SAST) model, J. Geophys. Res., 104, 19587-19579, 1999.

Szczypta, C., Decharme, B., Carrer, D., Calvet, J.-C., Lafont, S., Somot, S., Faroux, S., and Martin, E.: Impact of precipitation and land biophysical variables on the simulated discharge of European and Mediterranean rivers, Hydrol. Earth Syst. Sci., 16, 3351-3370, doi:10.5194/hess-16-3351-2012, 2012.

Vergnes, J.-P., Decharme, B., and Habets, F.: Introduction of groundwater capillary rises using subgrid spatial variability of topography into the ISBA land surface model, J. Geophys. Res.Atmos., 119, 11065-11086, doi:10.1002/2014JD021573, 2014.

Vernay, M., Lafaysse, M., Mérindol, L., Giraud, G., and Morin, S.: Ensemble forecasting of snowpack conditions and avalanche hazard, Cold Reg. Sci. Technol., doi:10.1016/j.coldregions.2015.04.010, in press, 2016.

Verseghy, D. L.: CLASS - a Canadian land surface scheme for GCMs. I: Soil model, Int. J. Climatol., 11, 111-133, 1991.

Vionnet, V., Brun, E., Morin, S., Boone, A., Faroux, S., Le Moigne, P., Martin, E., and Willemet, J.-M.: The detailed snowpack scheme Crocus and its implementation in SURFEX v7.2, Geosci. Model Dev., 5, 773-791, doi:10.5194/gmd-5-773-2012, 2012.

Walter, K. M., Zimov, S. A., Chanton, J. P., Verbyla, D., and Chapin, F. S.: Methane bubbling from Siberian thaw lakes as a positive feedback to climate warming, Nature, 443, 71-75, doi:10.1038/nature05040, 2006.

Wang, W., Rinke, A., Moore, J. C., Cui, X., Ji, D., Li, Q., Zhang, N., Wang, C., Zhang, S., Lawrence, D. M., McGuire, A. D., Zhang, W., Delire, C., Koven, C., Saito, K., MacDougall, A., Burke, E., and Decharme, B.: Diagnostic and model dependent uncertainty of simulated Tibetan permafrost area, The Cryosphere, 10, 287306, doi:10.5194/tc-10-287-2016, 2016. 
Warren, S.: Optical properties of snow, Rev. Geophys. Space Phys., 20, 67-89, 1982.

Wiscombe, W. J. and Warren, S. G.: A Model for the Spectral Albedo of Snow. I: Pure Snow, J. Atmos. Sci., 37, 2712-2733, doi:10.1175/1520-0469(1980)037<2712:AMFTSA>2.0.CO;2, 1980.

Yen, Y. C.: Review of thermal properties of snow, ice and sea ice, Tech. Rep. 81-10, Cold Reg. Res. and Eng. Lab., Hanover, NH, USA, 1-27, 1981.
Zeng, X., Dai, Y.-J., Dickinson, R. E., and Shaikh, M.: The role of root distribution for land climate simulation, Geophys. Res. Lett., 25, 4533-4536, 1998

Zhang, T., Barry, R., and Gilichinsky, D.: Russian historical soil temperature data. Digital media, National Snow and Ice Data Center, Boulder, 2001.

Zimov, S. A., Schuur, E. A. G., and Chapin, F. S.: Permafrost and the global carbon budget, Science, 312, 1612-1613, 2006. 